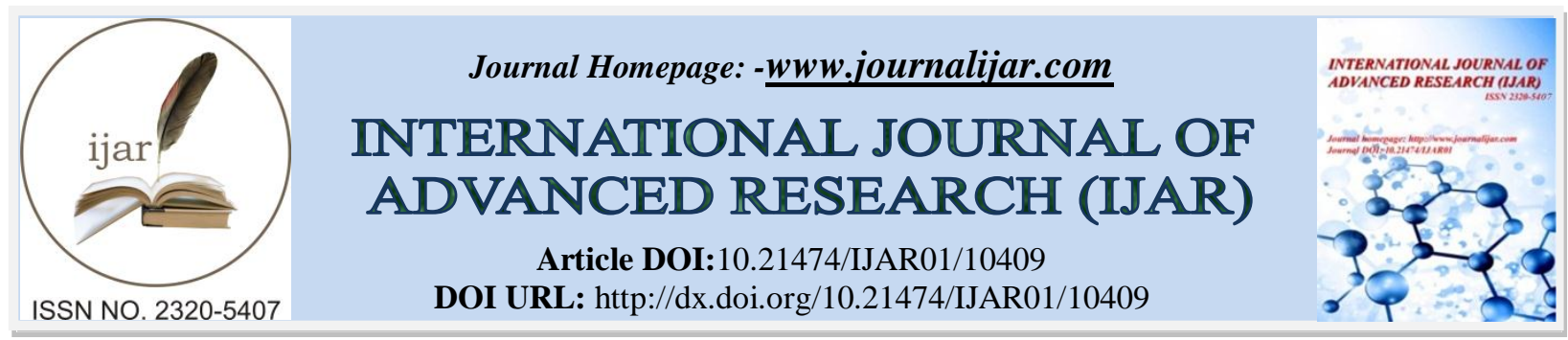

RESEARCH ARTICLE

\title{
EFFECT OF MATERNAL CONTACT, HOUSING SYSTEM AND PROBIOTICS SUPPLEMENTATION ON SOME PLASMA METABOLITES AND THYROID HORMONES LEVELS OF CAMEL-CALVES DURING WEANING PERIOD
}

\author{
Abdel-Fattah M.S., Hashem A.L.S., Reda A. Abd-Elazem, Azamel A.A. and Badawy M.T.A \\ Department of Animal Physiology, Animal and Poultry Production Division, Desert Research Center, Cairo, Egypt.
}

\section{Manuscript Info}

Manuscript History

Received: 30 November 2019

Final Accepted: 31 December 2019

Published: January 2020

Key words:-

Camel-Calves, Weaning, Housing System, Probiotics, Plasma Metabolites

\section{Abstract}

There are some factors influence on productive performance and physiological responses of camel-calves during weaning period. Mothering is an important factor for maintain the biological functions, immune-competence and calf survival. At weaning, calves were housed either with their dams or separated from their dams. Therefore, this study performed to investigate the effects of calf-dam contact system [completely contact system, (CCS) vs. completely separation system, (CSS)]; housing system [grouping, (G) vs. individually, (I)] and probiotics supplementation [control, (C) vs. probiotic, (P)] on some plasma biochemical parameters and thyroid gland activity of Maghreby camel-calves for 28 days period. Twenty female of camel calves aged 280 days with initial live body weight (LBW) of $236.76 \pm$ $0.224 \mathrm{~kg}$ were used. The study was carried out at Maryout Research Station of the Desert Research Center (DRC), Cairo, Egypt. Weekly blood plasma samples was analyzed for plasma total proteins (TP), albumin (A), plasma urea nitrogen (PUN), total cholesterol (CHO), triglycerides (TG), glucose (GLU), alanine amino transferase (ALT), aspartate amino transferase (AST), alkaline phosphatase (ALP), lactate dehydrogenase $(\mathrm{LDH})$ concentrations and thyroid gland activity $\left(\mathrm{T}_{3}\right.$ and $\mathrm{T}_{4}$ hormones) were determined. Results indicated that calf-dam contact system as Psychological stress and housing system as social stress, influenced significantly $(\mathrm{P}<0.05)$ on plasma TP, G, PUN, CHO, TG and GLU concentrations whereas the presence of dam and grouping housing system has the higher levels of these parameters compared with absence of dam and individually housing system. Calves housed under completely contact with their dams or grouped housing system has higher $(\mathrm{P}<0.05)$ concentrations in circulatory $\mathrm{T}_{3}$ and $\mathrm{T}_{4}$ hormones compared with calves separated from their dams or individually housed during weaning period, while probiotics supplementation had no statistically significant effect on circulatory $\mathrm{T}_{3}$ and $\mathrm{T}_{4}$ levels. Interactions of treatment and sampling time $(\mathbf{P}<0.01)$ were detected for plasma $T_{3}$ and $T_{4}$ levels under all three experimented factors. Liver enzymes (ALT, AST, ALP and LDH) activities were unaffected significantly $(\mathrm{P}>0.05)$ by calf-dam contact system, housing system and probiotics supplementation.It be concluded that camelcalves were more sensitive to the effects of calf-dam contact and 
housing system during weaning process. The results suggest that the calves remained with their dams and group-housing system can be the better as anti-psychological and social stressors than those separated from their dams or individually housed ones as management system at weaning process.

Copy Right, IJAR, 2020,. All rights reserved.

\section{Introduction:-}

There are different methods used for weaning process to evaluate the effects of these methods on dams and their offspring's. The common method of weaning performed by breeders are either early or late weaning (based on the age or body weights of young calves) and their effects on the reproductive performance of dams. Chibsaet al. (2014) recommended that weaning camel-calves at 8 months of age and supplemented concentrates to 12 months of age yield optimum growth rate and increase survivability of camel-calve. Recently, Orihuela and Galina, (2019) reviewed summarizes knowledge resulted in numerous published scientific studies on the separation of cows and calves and its effect on dams and their calves, where weaning stress is composed of the psychological stress of breaking maternal and social bonding and the physical stress of nutritional change. Weaning stress in animals is recognized as one cause of many health problems in cattle with important economic implications (Lee et al. 2008).

Weaning performed by breeders is sometimes associated with a complete separation of the two partners. Therefore, such practices may cause more profound behavioral and/or physiological disturbances (Orgeuret al, 1999). Also, Pérez et al. (2017) found that separation of the offspring has a stressful effect on both the mothers and the offspring as shown by the display of behaviors associated with stress, like vocalizations and locomotor activity, increase in cortisol concentration, loss of weight, and close proximity to fence-line, among others. Orihuela and Galina, (2019) mentioned that, although separation young calves from their mothers is stressful, keeping the calves in a familiar environment with other pen mates may allow them to adjust to separation from their dams more easily than moving them to an un-familiar pen (individually).

Early and McGee, (2011) mentioned that weaning can be a multifactor stressor, in which, nutritional, social, physical, and psychological stress are combined. Physical and nutritional stressors are often present through the introduction and adaptation to a new diet and new environment, whereas, psychological stress in the form of maternal separation and social disruption.

Lambs were generally found to be disturbed when they were separated from their mothers than when they were reunited (Abdul-Rahmanet al, 2012). Maternal separation has been identified as a potent stressor in infants and young animals that may have long-term psychological and physical effects Faturi et al., (2010). Abrupt weaning or separation of suckling calves from their dams is a common husbandry practice in both the beef and dairy industries. In 5 to 6-month old beef calves, abrupt maternal separation results in both the psychological stress of breaking the maternal bond as well as nutritional changes associated with dietary changes (Haley et al, 2005). In sheep, isolation of mothers from lambs has been shown to be a strong stress, particularly for the lamb (Niezgodaet al., 1993).

Previous study (LeNeindre, 1993) has assessed the effect on animal welfare of management stressors, such as isolation stress on productive performance during post-weaning period. The use of group housing might be beneficial when considering the welfare and socialization of the calf (Gulliksenet al., 2009). Group housing, containing 2 to 6 calves, provides more calf interactions and enriches their environment by adding stimulus (Stull and Reynolds, 2008). Besides housing systems, the type of diet and level of feeding are known to influence the hemato-biochemical parameters of animals (Katungukaet al. 1987). Studies on cattle suggest the physiological effects of separating a calf from its mother may contribute to a performance decrease several days after weaning. Physiological effects may be classified into three general categories; gross clinical signs, blood composition changes and endocrine interposed changes (Buenoet al, 1998).

Möstl and Palme, (2002) reported that there is a need for additional biochemical or endocrine parameters for detection of disturbances. Determination of the serum biochemistry reflects the physiological responsiveness of the animals to its internal and external environment (Esonuet al. 2001). The present study aimed to elucidate the influence of the presence of dams with their calves or the separation between them, housing system during postweaning period and the supplementation of probiotics on some blood plasma parameter0s and thyroid gland hormones of camel-calves. 


\section{Materials and Methods:-}

Animals and experimental procedure:-

The study was carried out at Maryout Research Station belonging to the Desert Research Center (DRC), Cairo, Egypt. Twenty females camel calves (Maghraby breed) were weaned using either completely contact system with their dams (CCS, 10 calves) or completely separation system from their dams (CSS, 10 calves) during weaning period under two housing systems [6 calves in grouping (G) and 4 calves in individually (I) housing system], half of calves in each housing system were supplemented with probiotics $(\mathrm{P})$, while the other half was not-supplemented with probiotics (C). Calves were weaned at 280 days of age with initial live body weight (LBW) of $236.76 \pm 0.224$ $\mathrm{kg}$ (pictures from 4 to 9 showing maternal contact system, housing system and probiotics supplementations).

All calves were fed commercial concentrate mixture to meet nutrient requirements for a post-weaning period to achieve adequate growth as suggested by Davis and Drackley (1998). Commercial concentrate feed mixture (CFM) was fed once a day in the morning (at 08:00 am). All calves had clover hay $(\mathrm{CH})$ ad libitum as roughage throughout the experiment. The chemical composition of CFM and $\mathrm{CH}$ (on DM basis \%) are presented in Table (1). Proximate analyses were determined by the standard AOAC (2005), while nitrogen-free extract (NFE) was determined by the calculated difference. Fresh water was offered once daily. All calves, were provided free-choice access to a saltbased trace mineral mix that contained $12.0 \% \mathrm{Ca}, 9.0 \% \mathrm{~B}, 9.0 \% \mathrm{Na}, 0.30 \% \mathrm{Zn}, 0.15 \% \mathrm{Cu}, 0.05 \% \mathrm{Mn}, 0: 02 \% \mathrm{I}$, $0.005 \% \mathrm{Co}$, and $0.004 \% \mathrm{Se}$; in a blocks form.

Table1:- The chemical composition (on DM basis, \%) of concentrate feed mixture (CFM) and clover hay (CH).

\begin{tabular}{|l|l|l|l|l|l|l|l|}
\hline Item & DM & OM & CP & CF & EE & Ash & NEF \\
\hline CFM $^{*}$ & 92.83 & 92.79 & 16.97 & 10.21 & 4.37 & 7.44 & 61.01 \\
\hline CH & 90.77 & 84.91 & 14.84 & 24.83 & 1.78 & 15.03 & 43.52 \\
\hline
\end{tabular}

"CFM: concentrate feed mixture contained; $36 \%$ yellow corn; $31 \%$ un-decorticated cotton seed; $19 \%$ wheat bran; $7.5 \%$ rice bran $; 2.5 \%$ molasses; $3 \%$ limestone and $1 \%$ common salt.

\section{Anti-suckling mean:-}

For calves (10 calves) under completely contact with their dams system (CCS-calves), the appealing to use antisuckling mean for dams to prevent calves from nursing while allowing the calf and their dam to remain together because it facilitates a relatively low-stress weaning approach. The simple common form of anti-suckling is tie of thick cloth coated the dam udder, so that the calf cannot get the teat into its mouth to nurse. This type of antisuckling mean is low cost and can be reused (Pictures 1:3).

\section{Preparation of probiotics:-}

A probiotic compound (BIOVET-YC) was used where each kg containing 7.500 x $10^{6}$ c.f.u.Lactobacillussporogenes; $30.000 \times 10^{6}$ c.f.u. ; $125.000 \times 10^{6}$ c.f.uSaccharomyces cerevisia SC-47; $5 \mathrm{~g}$ Alpha amylase; $100 \mathrm{~g}$ sea wood powder and q.s excipient. $20 \mathrm{~g}$ BIOVET-YC was dissolved in $200 \mathrm{ml}$ warm fresh water plus $30 \mathrm{ml}$ molas. This dose of probiotics was given involuntary and orally to each calf in probiotics supplemented group daily at 10:00 am by using drench-revolver at the beginning of weaning and lasted 28 days. Same volume $(220 \mathrm{ml})$ of fresh water plus 30 $\mathrm{ml}$ molas was also given to each calf in un-supplemented probiotics calves once daily at 10:00 am by using drenchrevolver.

\section{Blood collection and biochemical analysis:-}

Weekly blood sample was collected via jugular venipuncture into $10 \mathrm{ml}$ vacutainer tubes containing Lithium heparin as anticoagulant. Plasma samples were analyzed for total proteins (TP, g/dl), albumin (A, g/dl), urea nitrogen (PUN, mg/dl), triglycerides ( $\mathrm{TG}, \mathrm{mg} / \mathrm{dl}$ ), cholesterol (CHO, mg/dl), and glucose (GLU, mg/dl) concentrations were estimated using kits from Hoffmann-La-Roche. Alanine aminotransferase (ALT,u/l), aspartate aminotransferase (AST,u/l) were determined according to Retiman andFrankel (1957). Alkaline phosphatase (ALP, $\mathrm{u} / \mathrm{l}$ ) was estimated according to Roy (1970) and lactate dehydrogenase (LDH, u/l) estimated using available kits supplied by bio Me'ricux-france. Concentrations of Triiodothyronine $\left(\mathrm{T}_{3}, \mathrm{ng} / \mathrm{dl}\right)$ and Thyroxine $\left(\mathrm{T}_{4}, \mu \mathrm{g} / \mathrm{dl}\right)$ hormones were determined with RIA as recently described (Hammon and Blum 1998). Globulin was calculated (as the difference between total proteins and albumin).

Statistical analysis:-

Data analyses were conducted using General Linear Model (GLM) procedures (SAS,2008). Data were analyzed using an analysis of variance for a repeated measures design. Sources of variation included calf-dam contact system, 
housing system, probiotics supplementation and their interactions. Mean comparisons were evaluated by Duncan's Multiple Range Test (1955), least significant difference with a single degree of freedom. a= $(\mathrm{P}<0.05)$ level of significance was chosen.

\section{Results and Discussion:-}

We found relevant interactions among the three main studied factors (calf-dam contact system as psychological stress, housing system as social stress and probiotics supplementation as biological additives); therefore, the obtained results of blood plasma parameters and thyroid gland activity under each factor will be discussed independently from the other factors as follow:

\section{Maternal contact effect (Psychological stress): Plasma metabolites, Plasma proteins:}

Plasma concentrations of TP, A, G and A/G ratio are shown in Table 2. Regarding the effect of calf-dam contact system solely, results indicated that separation of calves from their dams during weaning period declined significantly $(\mathrm{P}<0.01)$ plasma $\mathrm{TP}$ and $\mathrm{G}$ concentrations while $\mathrm{A}$ and $\mathrm{A} / \mathrm{G}$ ratio increased $(7.67,3.11,4.65 \mathrm{~g} / \mathrm{dl}$ and $0.67 \%$ ) compared with calves under completely contact with their dams $(8.06,2.91,5.15 \mathrm{~g} / \mathrm{dl}$ and $0.56 \%$ ). This reduction suggests that maternal separation caused psychological stress by breaking the stable bonds between calves and their dams and subsequently some biological problems may arise. Hickey et al. (2003) mentioned that weaning stress lead to break the social bond between the calf and its dam in addition disrupts their familiar social which is an inherent aspect of weaning. Also, Stehulovaet al. (2003) mentioned that the cow-calf separation has been reported to be stressful to cows and calves.

Statistical analysis showed that there is a significant effect of the interaction between treatment and sampling time $(\mathrm{P}<0.05)$. Fig.(1) illustrated that Plasma TP and A concentrations decreased rapidly in both CCS-calves and CSScalves on $\mathrm{D}_{7}$ post-weaning as a result of immunoglobulin absorption into blood circulatory, this might explain the response to the effect of the a abrupt shifting from liquid to solid feeds. In accordance, Coppo, (2000) and Coppoet al, (2003) reported that plasma TP, A, PUN, CHO and TG as indicators of nutrition state were significantly lower in early weaned calves than control, these modifications could be attributed to nutritional imbalances caused by change of the feeding method. Atasogluet al. (2008) reported that plasma total protein concentration increased $(\mathbf{P}<0.001)$ significantly by the periods in weaned kids during post-weaning.

As shown in Fig. (1), plasma TP and G concentrations tended to significantly increase $(\mathrm{P}<0.05)$ for $\mathrm{CCS}$-calves compared with CSS-calves, while plasma A concentration was stable in both CCS-calves and CSS-calves from $\mathrm{D}_{14}$ till $\mathrm{D}_{28}$. Therefore, the increase in plasma TP associated with elevated globulin concentrations. This increase in plasma $\mathrm{G}$ concentration indicates improving the immune status in CCS-calves than CSS-calves. Accordingly, the interactions between treatment and sampling time resulting changes in plasma proteins concentrations and is considered important factor in the plasma proteins traits of stressed calves. Peak values of plasma TP and G concentrations of both CCS and CSS-calves were observed at $\mathrm{D}_{21}$ of experimental period.

\section{Liver and kidney functions:-}

Means of PUN, CHO, TG and GLU concentrations for CCS-calves and CSS-calves are presented in Table 2. Concerning the effect of calf-dam contact system, results indicated that PUN, CHO, TG and GLU concentrations increased significantly $(\mathrm{P}<0.01)$ in CCS-calves $(39.08,51.50,34.62$ and $108.20 \mathrm{mg} / \mathrm{dl})$ compared with CSS-calves (35.01, 48.42, 30.96 and $104.54 \mathrm{mg} / \mathrm{dl})$. In contrast, Ali et al. (2015) reported that, lambs weaned at age of 45 days had more stress when compared with lambs weaned at 90 days based on the observed increase in blood glucose and urea nitrogen when lambs were completely separated from their dams.

(Fig.2) stated that there was a significant effect of the interaction between treatment and sampling time $(\mathrm{P}<0.05)$ where plasma PUN, CHO and TG concentrations had increased with the advancement of sampling time in both groups, but CCS-calves had the higher in rate of change (14.67, 10.75 and 25.71\%) compared with CSS-calves $(2.84,4.37$ and $12.70 \%)$ for PUN, CHO and TG, respectively. Atasogluet al. (2008) reported that plasma glucose urea and cholesterol concentrations were significantly $(\mathbf{P}<0.003)$ affected by the periods in weaned kids during post-weaning. In agreement, Yanchevet al. (2008) reported that glucose levels increased significantly (P<0.01) by 4 and 9 days following weaning in Black-and-White calves, thus the increased plasma GLU level after weaning could reflect a new level of homeostatic balance aimed at reducing cortisol induced gluconeogenesis, by maintaining low plasma cortisol level. In contrast, they also reported that plasma urea and cholesterol levels following weaning 
declined significantly in Black-and White calves. Coppo, (2001) reported that the early weaning of calves caused significantly $(\mathrm{P}<0.05)$ increase in plasma GLU concentration and suggested that this increase could probably be attributed to medulla-adrenal sympathetic alarms caused by handling, blood sampling, feeding system change and separation of the calves from their dams.

\section{Enzymes activity response:-}

Concerning the effect of maternal contact system, results in Table 2 indicated that there were non-significant differences in plasma ALT, AST, ALP and LDH levels between CCS-calves (10.54, 29.98, 81.72 and $473.75 \mathrm{u} / \mathrm{l})$ and CSS-calves $(10.62,30.30,80.96$ and $472.96 \mathrm{u} / \mathrm{l})$, respectively. As shown in Figure (3) plasma ALT, AST and ALP enzymes decreased significantly $(\mathrm{P}<0.01)$ in both CCS-calves and CSS-calves on D7 followed by significantly increase $(P<0.01)$ from $\mathrm{D}_{14}$ till the end of study $\left(\mathrm{D}_{28}\right)$. The observed decrease in plasma ALT, AST and ALP levels on D7 indicated to the acute response of weaning shock in both groups; while, the similarity increase in these parameters reflect the healthy indicator of liver function for all calves. No main or interactions with sampling time for CSS group were detected on all plasma enzymes activity during pot-weaning. Oler and Glowinska, (2013) mentioned that ALT and AST are enzymes associated with liver parenchymal cells, when body tissue or an organ, such as the liver, is diseased or damaged, AST is released into the blood; thus, the amount of that enzyme in the blood is related to the extent of damage.

Table 2:- Effect of Calf-dam contact system (CCS vs. CSS), housing system (G vs. I) and probioticspplementation (C vs. P) on plasma metabolites of camel-calves during weaning period.

\begin{tabular}{|c|c|c|c|c|c|c|c|c|c|}
\hline \multirow[t]{2}{*}{ Traits } & \multicolumn{3}{|c|}{$\begin{array}{l}\text { Maternal contact } \\
\text { System }\end{array}$} & \multicolumn{3}{|c|}{ Housing system } & \multicolumn{3}{|c|}{$\begin{array}{l}\text { Probiotics } \\
\text { supplementation }\end{array}$} \\
\hline & CCS & CSS & $\pm \mathrm{SE}$ & G & I & \pm SE & $\mathrm{C}$ & $\mathbf{P}$ & $\pm \mathrm{SE}$ \\
\hline TP, g/dl & $8.06^{\mathrm{a}}$ & $7.67^{b}$ & 0.02 & $8.30^{\mathrm{a}}$ & $7.95^{\mathrm{b}}$ & 0.02 & $7.71^{b}$ & $8.32^{\mathrm{a}}$ & 0.02 \\
\hline $\mathrm{A}, \mathrm{g} / \mathrm{dl}$ & $2.91^{\mathrm{b}}$ & $3.11^{\mathrm{a}}$ & 0.01 & $3.29^{\mathrm{a}}$ & $2.93^{\mathrm{b}}$ & 0.01 & $3.02^{\mathrm{a}}$ & $2.99^{\mathrm{b}}$ & 0.01 \\
\hline $\mathrm{G}, \mathrm{g} / \mathrm{dl}$ & $5.15^{\mathrm{a}}$ & $4.65^{\mathrm{b}}$ & 0.02 & $4.99^{\mathrm{a}}$ & $5.02^{\mathrm{a}}$ & 0.03 & $4.68^{\mathrm{b}}$ & $5.33^{\mathrm{a}}$ & 0.02 \\
\hline A/G ratio & $0.56^{\mathrm{b}}$ & $0.67^{\mathrm{a}}$ & 0.01 & $0.63^{\mathrm{a}}$ & $0.60^{\mathrm{b}}$ & 0.01 & $0.65^{\mathrm{a}}$ & $0.60^{\mathrm{b}}$ & 0.21 \\
\hline PUN, mg/dl & $39.08^{\mathrm{a}}$ & $35.01^{b}$ & 0.25 & $35.42^{\mathrm{a}}$ & $34.75^{\mathrm{b}}$ & 0.26 & $34.54^{b}$ & $35.62^{\mathrm{a}}$ & 0.35 \\
\hline $\mathrm{CHO}, \mathrm{mg} / \mathrm{dl}$ & $51.50^{\mathrm{a}}$ & $48.42^{b}$ & 0.35 & $51.92^{\mathrm{a}}$ & $48.00^{\mathrm{b}}$ & 0.34 & $47.70^{b}$ & $52.52^{\mathrm{a}}$ & 0.33 \\
\hline TG, mg/dl & $34.62^{\mathrm{a}}$ & $30.96^{b}$ & 0.50 & $33.83^{\mathrm{a}}$ & $31.75^{\mathrm{b}}$ & 0.29 & $32.96^{\mathrm{b}}$ & $35.62^{\mathrm{a}}$ & 0.29 \\
\hline GLU, mg/dl & $108.20^{\mathrm{a}}$ & $104.54^{b}$ & 0.50 & $109.58^{\mathrm{a}}$ & $108.98^{\mathrm{b}}$ & 0.50 & $106.92^{\mathrm{a}}$ & $105.7^{b}$ & 0.50 \\
\hline $\operatorname{ALT}(\mathbf{u} / \mathbf{l})$ & $10.54^{\mathrm{a}}$ & $10.62^{\mathrm{a}}$ & 0.08 & $10.55^{\mathrm{b}}$ & $10.37^{\mathrm{a}}$ & 0.09 & $10.56^{\mathrm{a}}$ & $10.60^{\mathrm{a}}$ & 0.08 \\
\hline $\operatorname{AST}(\mathbf{u} / \mathbf{l})$ & $29.98^{\mathrm{a}}$ & $30.30^{\mathrm{a}}$ & 0.25 & $29.97^{\mathrm{a}}$ & $29.90^{b}$ & 0.28 & $29.90^{\mathrm{a}}$ & $30.30^{\mathrm{a}}$ & 0.25 \\
\hline $\operatorname{ALP}(\mathbf{u} / \mathbf{l})$ & $81.72^{\mathrm{a}}$ & $80.96^{\mathrm{a}}$ & 0.60 & $81.67^{\mathrm{a}}$ & $80.71^{\mathrm{a}}$ & 0.60 & $81.30^{\mathrm{a}}$ & $81.10^{\mathrm{a}}$ & 0.60 \\
\hline LDH (u/l) & $473.75^{\mathrm{a}}$ & $472.96^{\mathrm{a}}$ & 0.19 & $474.42^{\mathrm{a}}$ & $471.75^{\mathrm{a}}$ & 1.1 & $474.1^{\mathrm{a}}$ & $473.9^{\mathrm{a}}$ & 0.19 \\
\hline$T_{3}(n g / d l)$ & $2.66^{\mathrm{a}}$ & $2.51^{\mathrm{b}}$ & 0.28 & $2.69^{\mathrm{a}}$ & $2.44^{\mathrm{b}}$ & 0.28 & $2.57^{\mathrm{a}}$ & $2.56^{\mathrm{a}}$ & 0.27 \\
\hline$T_{4}(\mu \mathrm{g} / \mathrm{dl})$ & $168.21^{\mathrm{a}}$ & $144.20^{\mathrm{b}}$ & 0.55 & $164.12^{\mathrm{a}}$ & $162.37^{\mathrm{b}}$ & 0.60 & $165.1^{\mathrm{a}}$ & $164.9^{\mathrm{a}}$ & 0.60 \\
\hline
\end{tabular}

$\mathrm{CCS}=$ completely contact system, $\mathrm{CSS}=$ completely separation system, $\mathrm{G}=$ grouping housing, $\mathrm{I}=$ individually housing, $\mathrm{C}=$ control group, $\mathrm{P}=$ probiotics group, $\mathrm{TP}=$ total protein; $\mathrm{A}=$ albumin, $\mathrm{G}=$ globulin; $\mathrm{A} / \mathrm{G}=$ albumin/globulin ratio; $\mathrm{PUN}=$ plasma urea nitrogen; $\mathrm{CHO}=$ cholesterol; $\mathrm{TG}=$ triglycerides; $\mathrm{GLU}=$ glucose; $\mathrm{ALT}=$ alanine amino transferase; $\mathrm{AST}=$ aspatate amino transaminase; $\mathrm{ALP}=$ alkaline phosphatase; $\mathrm{LDH}=$ lactate dehydrogenase; $\mathrm{T}_{3}=$ triiodothyronine hormone, $\mathrm{T}_{4}=$ thyroxine hormone ${ }^{\mathrm{a}, \mathrm{b}}=$ different letters indicate significant differences within the same raw $(\mathrm{P}<0.05)$

\section{Thyroid hormones response:-}

Regarding the effect of calf-dam contact system; results indicated that both groups (CCS vs. CSS) influenced to weaning shock where CSS-calves recorded the lower levels of plasma $\mathrm{T}_{3}$ and $\mathrm{T}_{4}\left(2.04 \mathrm{ng}^{-1} \mathrm{ml}\right.$ and $\left.157.24 \mu \mathrm{g}^{-1} \mathrm{dl}\right)$ during the first week $\left(\mathrm{D}_{7}\right)$ compared with CCS-calves $\left(2.19 \mathrm{ng}^{-1} \mathrm{ml}\right.$ and $\left.159.77 \mu_{\mathrm{g}}{ }^{-1} \mathrm{dl}\right)$. This difference could be attributed to the effect of the higher level of imposed stresses (the shift from liquid to solid feeding and completely maternal deprivation) for CSS-calves than CCS-calves. Therefore, this type of weaning (completely separation between calves and their dams) may be cause a lot of stresses to both mother and young that are express for both calves and their dams in their physiological responses. At the second week $\left(D_{14}\right)$ the levels of $T_{3}$ and $T_{4}$ recorded 
$2.31 \mathrm{ng}^{-1} \mathrm{ml}$ and $161.23 \mu \mathrm{g}^{-1} \mathrm{dl}$ for CSS-calves versus $2.39 \mathrm{ng}^{-1} \mathrm{ml}$ and $163.54 \mu \mathrm{g}^{-1} \mathrm{dl}$ for CCS-calves. This finding stated that plasma $\mathrm{T}_{3}$ was the lower while plasma $\mathrm{T}_{4}$ increased for CCS-calves. In agreement, Fazio et al., (2015) reported that weaned lambs showed significantly decrease in serum $\mathrm{T}_{3}$ and elevated $\mathrm{T}_{4}$ concentrations at two weeks after weaning where weaning was done by abrupt visual and acoustical separation of the ewe and lamb. Therefore, calves were allowed continuous contact with their dams not marked stress response for thyroid gland activity. Thereafter plasma $\mathrm{T}_{3}$ and $\mathrm{T}_{4}$ concentrations for CSS-calves increased $(\mathrm{P}<0.01)$ significantly from $\mathrm{D}_{14}$ till the end of study $\left(\mathrm{D}_{28}\right)$ where their values of $\mathrm{T}_{3}$ and $\mathrm{T}_{4}$ on $\mathrm{D}_{28}$ were nearly to the values of $\mathrm{T}_{3}$ and $\mathrm{T}_{4}$ for CCS- calves. (2.53 ng ${ }^{1} \mathrm{ml}$ and $167.92 \mu \mathrm{g}^{-1} \mathrm{dl}$ vs. $2.62 \mathrm{ng}^{-1} \mathrm{ml}$ and $\left.168.61 \mu \mathrm{g}^{-1} \mathrm{dl}\right)$. Therefore, calves were allowed continuous contact with their dams had lower stress on thyroid activity. Dvorak and Neumannova (1986) reported increased serum concentration of $\mathrm{T}_{4}$ among piglets in response of weaning induced stimulated adrenocortical activity. They suggested that both specific stressor effects and circulating corticosteroids are responsible for the changes of $\mathrm{T}_{3}$ and $\mathrm{T}_{4}$ concentrations in blood sera of weaned animals. The significant changes of total iodothyronines in weaned camel-calves confirm data previously observed in foals after weaning, hence the thyroid responses may, therefore, be the physiological consequence of post-weaning adaptations and may be both the cause and/or the consequence of growth programming, confirming previous results obtained in growing foals (Fazio et al. 2007).
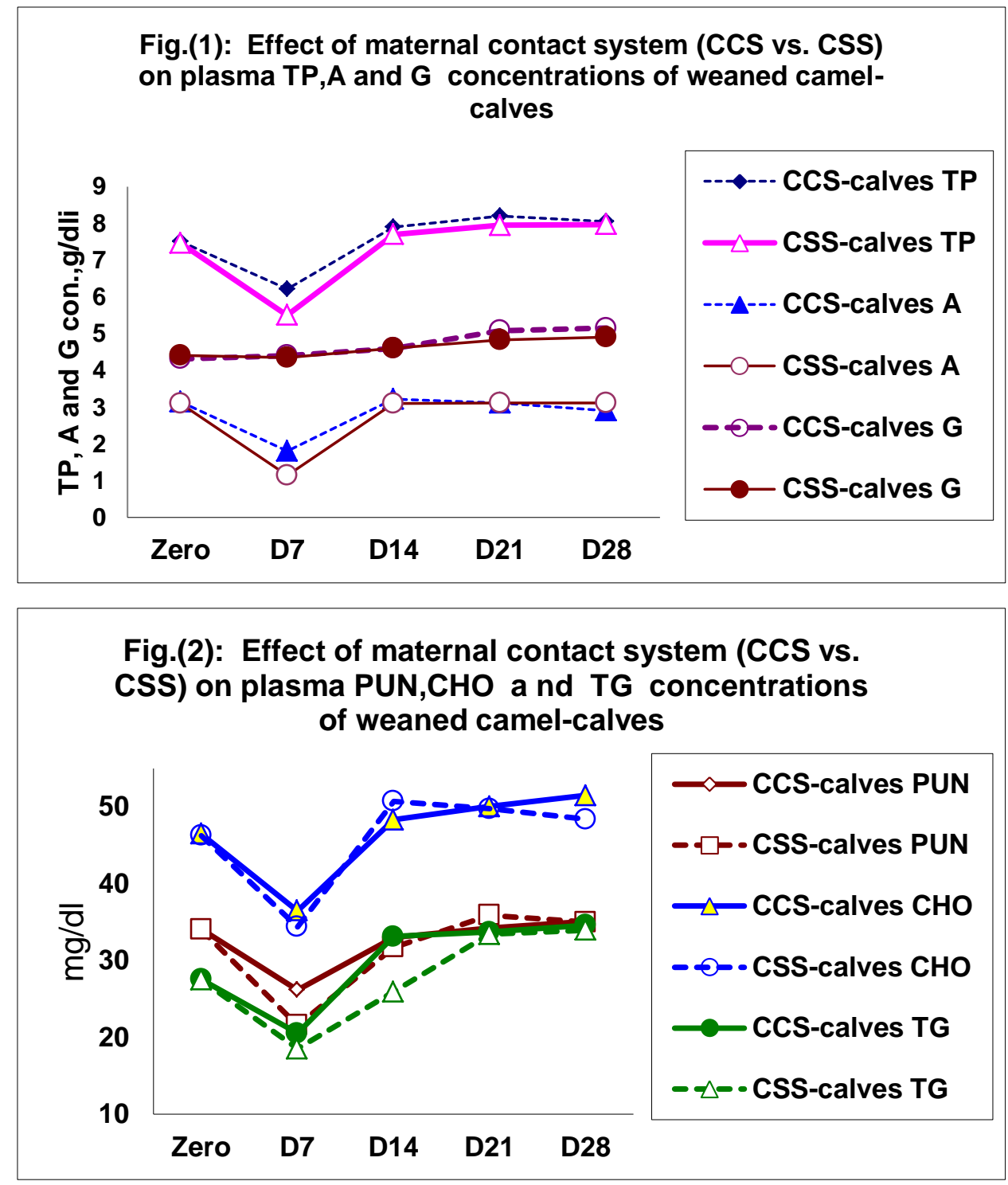


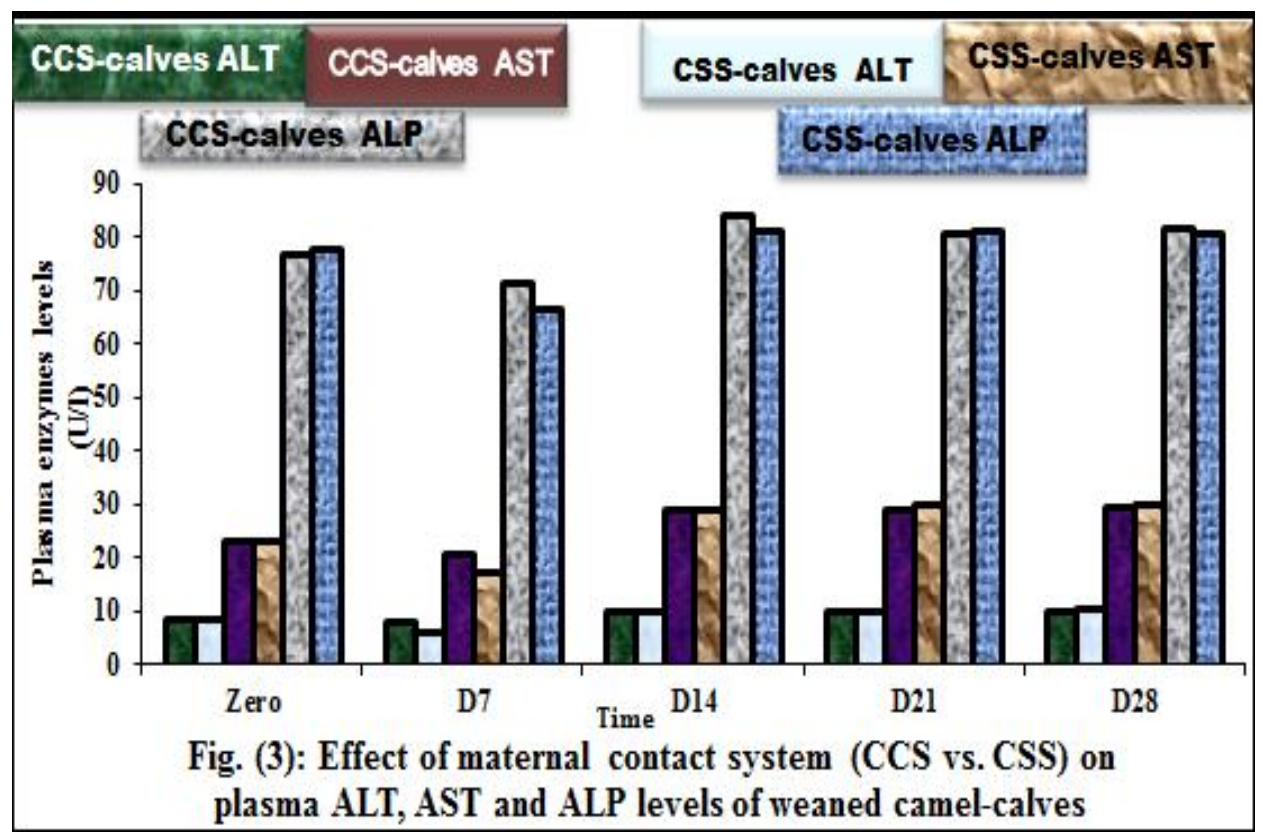

Housing system effect:-

Plasma proteins:-

With respect the effect of housing system [grouping (G) vs. individually (I)], the obtained results in Table 2 indicated that plasma TP, A, G and A/G ratio increased significantly $(\mathrm{P}<0.05)$ in G-calves $(8.30,3.29,4.99$ and 0.63) compared with I-calves $(7.95,2.93,5.02 \mathrm{~g} / \mathrm{dl}$ and $0.60 \%)$. In accordance, Babuet al. (2009) reported that plasma total protein increased in group housed calves compared with individually housed calves. In disagreement, Maccariet al. (2014) found that serum albumin was higher at an age of 21 days under individually housing calves in relation to grouped housing calves. Abd-Allah et al., (2015) reported that plasma total protein and albumin levels increased significantly $(\mathrm{P} \leq 0.01)$ in calves housed individually than calves housed in groups, in spite of plasma globulin concentration remained lower in buffalo calves treated by two housing systems (group vs. individually). There was interaction $(\mathrm{P}<0.05)$ between housing system and sampling time on plasma concentrations of $\mathrm{TP}, \mathrm{G}$ and $\mathrm{A} / \mathrm{G}$ ratio for both grouped and individually housed calves from $\mathrm{D}_{14}$ till the end of experimental period except on $\mathrm{D}_{7}$ (Fig.4), this could suggest that calves have more difficulty adapting to the housing system during the first week after weaning.

\section{Liver and kidney functions:-}

Regarding the effect of housing system [grouping (G) vs. individually (I)], the obtained results in Table 3 indicated that, plasma PUN, CHO, TG and GLU concentrations were significantly higher $(\mathrm{P}<0.05)$ in G-calves $(35.42,51.92$, 33.83 and $109.58 \mathrm{mg} / \mathrm{dl})$ compared with I-calves $(34.75,48.00,31.75$ and $108.98 \mathrm{mg} / \mathrm{dl})$. In accordance, Terréet al. (2006) and Babuet al. (2009) reported that serum urea concentrations were greater $(\mathrm{P}<0.01)$ in grouped calves than in individually housed calves during post-weaning. Abd-Allah et al., (2015) reported that plasma cholesterol concentration remained lower in buffalo calves treated by two housing systems (group vs. individually).

Lynch et al, (2010) reported that weaning and subsequent housing caused transient changes in blood metabolites. In contrast, Maccariet al. (2014) found that serum glucose and urea were higher at age of 21 days under individually housing calves compared to grouped housing calves. On the other hand, Marco et al. (1997)reported that serum CHO level declined significantly during capture stress in adult sheep. Both Pierzchalaet al., (1985) and Niezgodaet al. (1987) found that plasma glucose concentration increased during the initial 2 hour after exposing sheep to isolation stress; however, glucose concentrations quickly returned to levels associated with non-stressed sheep. Gibert, 1991reported that capture stress response caused an increase in serum urea concentration in wild ungulates. Montaneet al (2003) reported that increase in serum urea concentration $(\mathrm{P}<0.05)$ over time was observed as response to capture stress in roe deer. Apple et al. (2005) reported that plasma concentrations of glucose was higher $(\mathrm{P}<0.05)$ in calves under restraint and isolation stress than in unstressed calves after 80 and 100 minutes of stressor application. Likewise, Apple et al. (1993) reported that glucose concentration elevated in restraint and isolated 
lambs at the final stressor bout, although serum glucose concentration was unaffected till 18 hours after termination of stressor application.

Concerning the effect of sampling time results showed that in almost sampling time's plasma PUN, CHO and TG were higher for G-calves than I-calves (Fig.5). The rate of change for PUN, CHO, TG and GLU recorded 4.95, 11.20, 21.50 and 1.30\%vs. 1.05, 4.10,16.22 and 1.30\% for G-calves and I-calves, respectively. Statistical analysis showed that there was interaction between housing system and sampling time $(\mathrm{P}<0.01)$. Results indicated that plasma TG was not significant differed between $\mathrm{G}$ and I housed calves. Investigations along experimental period revealed that an opposite trend (reducing) for the levels of PUN, CHO and TG parameters at the first sampling time $\left(D_{7}\right)$ which may be attributed to the effect of weaning shock. Therefore, the superior of G-calves in these parameters is a good indicator of immune activity in G-calves than I-calves and may be this difference are symbolizing to an act of the beneficial effect of socialization which was obviously absent in individually or isolated housed calves.

\section{Enzymes activity response:-}

Concerning the effect of housing system, results in Table 2 indicated that ALT, AST, ALP and LDH activities were not significantly differed between G-calves (10.55, 29.97, 81.67 and 474.42u/1 , respectively) and I-calves (10.37, 29.90, 80.71 and 471.75u/1 , respectively). However, Abd-Allah et al., (2015) reported that plasma ALT was significantly $(\mathrm{P} \leq 0.05)$ affected by the housing system; the level of this enzyme was higher in calves housed individually than calves housed in groups. In spite of plasma AST level remained lower in calvesraised in groups than calves raised as individual but this reduction was not statistically significant. Apple et al. (1993) reported that serum alkaline phosphatase had lower $(\mathrm{P}<0.05)$ concentration of lambs under restraint and isolation stress (RIS) for $6 \mathrm{~h}$ on three consecutive days than did unstressed lambs, while serum glutamic oxaloacetic transaminase (GOT) was increased $(\mathrm{P}<0.05)$ 20- to 30-fold in RIS lambs compared with unstressed lambs.

\section{Thyroid hormones response:-}

Regarding the effect of housing system, results in Table (2) indicated that grouped housed calves showed significantly $(\mathrm{P}<0.05)$ higher levels for both plasma $\mathrm{T}_{3}$ and $\mathrm{T}_{4}$ being $2.69 \mathrm{ng}^{-1} \mathrm{ml}$ and $164.12 \mu \mathrm{g}^{-1} \mathrm{dl}$ compared with individually housed calves $\left(2.44 \mathrm{ng}^{-1} \mathrm{ml}\right.$ and $162.37 \mu \mathrm{g}^{-1} \mathrm{dl}$ for $\mathrm{T}_{3}$ and $\mathrm{T}_{4}$, respectively). On the contrary, Wronskaet al. (1990) found that isolation stress acting on fed and fasting sheep groups where increased significantly $\mathrm{T}_{3}, \mathrm{~T}_{4}$ hormones and glucose levels. Friend et al. (1985) reported higher thyroid hormones levels in individually housed calves than in group-housed calves. Mal et al. (1991) found that concentrations of plasma $\mathrm{T}_{3}$ were higher in isolated mares than in control (allowing social contact) and P (pasture) mares. On the other hand, Casamassimaet al. (2001) reported that neither free- $\mathrm{T}_{3}$ nor free- $\mathrm{T}_{4}$ blood levels were changed by housing system of ewes.

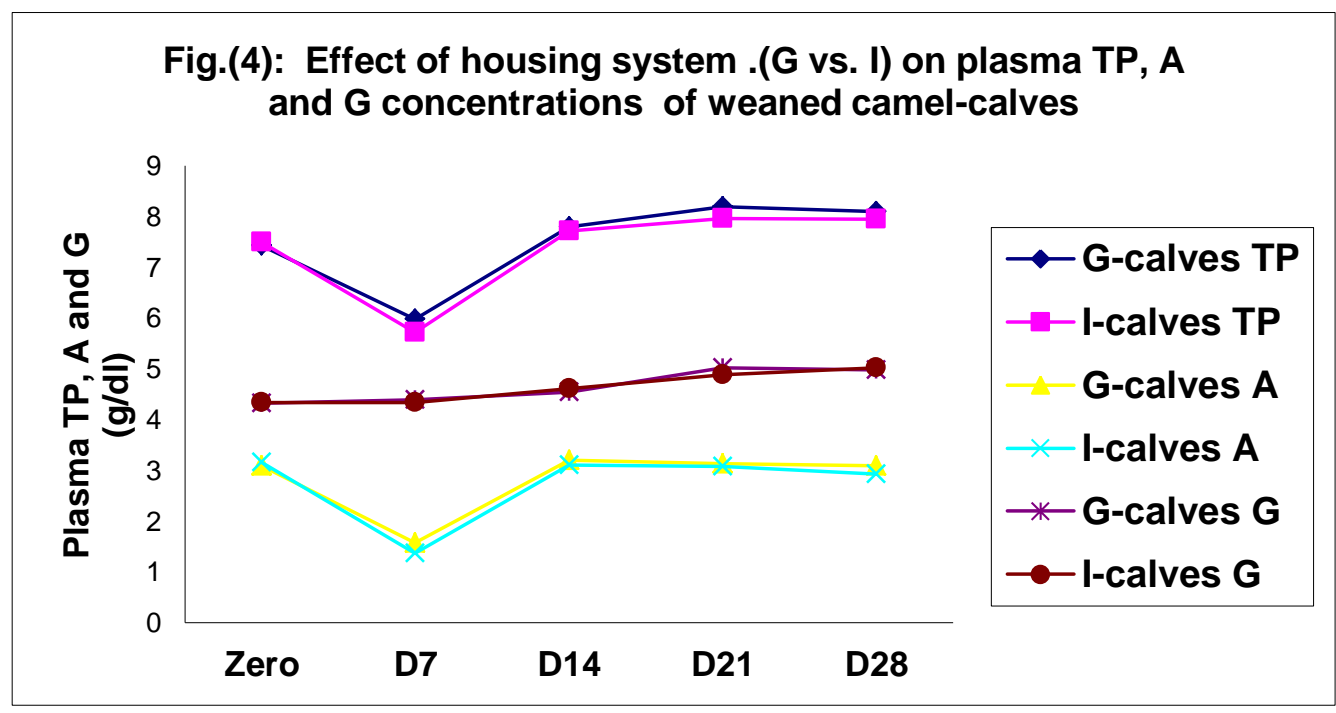




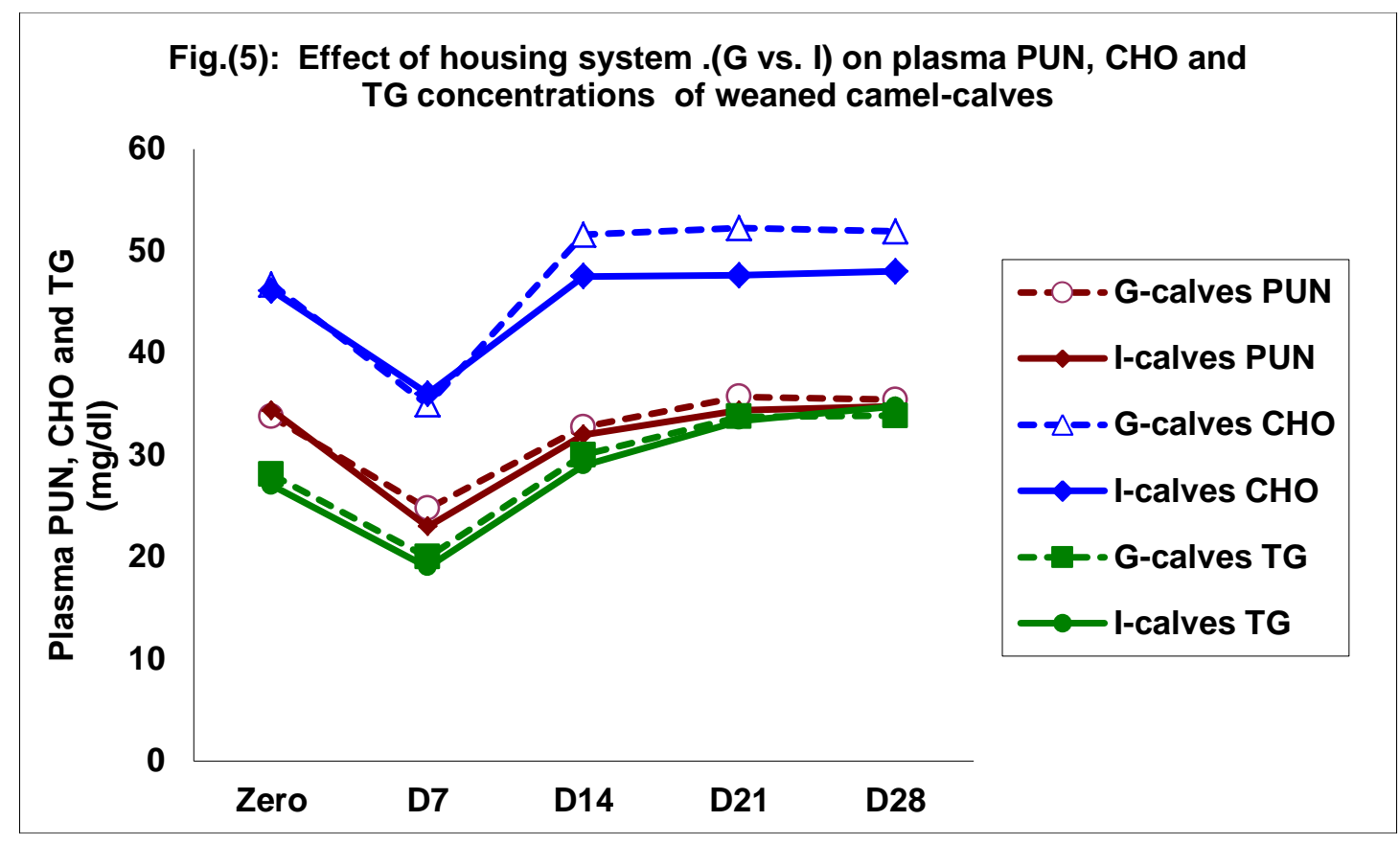

\section{Probiotics effect:-}

\section{Plasma metabolites:-}

\section{Plasma proteins response:-}

Results in Table (2) indicated that there were significant increase $(\mathrm{P}<0.01)$ in plasma TP and G concentrations for $\mathrm{P}$ calves $(8.32$ and $5.33 \mathrm{~g} / \mathrm{dl})$ compared with C-calves $(7.71$ and $4.68 \mathrm{~g} / \mathrm{dl})$ while plasma A concentration and $\mathrm{A} / \mathrm{G}$ ratio decreased significantly where the average values recorded 2.99 and $0.60 \mathrm{vs.} 3.02 \mathrm{~g} / \mathrm{dl}$ and $0.65 \%$ for P-calves and $\mathrm{C}$-calves, respectively. There was interaction between treatment and sampling time $(\mathrm{P}<0.05)$, the initial values of TP, A, G and A/G ratio were identical in both groups and responded similarly whereas TP and A sharply declined while $G$ was stable at $D_{7}$ post-weaning, followed by increasing TP and G levels from $D_{14}$ till the end of study $\left(D_{28}\right)$. P-calves was had the higher values than C-calves (Fig.6). The rate of change for TP, A, G and A/G ratio recorded (3.22, -2.6, 7.83 and $-9.7 \%$ vs. 11.7, -4.46, 23.09 and -16.7\%) for C-calves and P-calves, respectively. The higher TP level in P-calves than C-valves may be attributed to the increase in digestibility of crud protein (Yousef and Zaki, 2001). This confirmed by Putnam and Schwab (1994) who reported that YC stimulates rumen microbes that altered microbial protein synthesis and increased protein passage as well as protein yield. Also Komonna,( 2007) and Mousaet al. (2012) who found that there was a better utilization of dietary protein through digestive tract after treatment with Saccharomyces cerevisiae.

Our results were paralleled with that recorded by Bakret al. (2009) who reported a significant increase in the levels of serum total proteins of buffalo calves supplemented probiotics. Recently, Izuddinet al. (2019); Ghoneem and Mahmoud. (2014) reported that plasma TP and PUN concentrations increased significantly $(\mathrm{P}<0.05)$ with lambs supplemented with postbiotics and inactivated yeast as feed additives, respectively. These results may be due to the improvement in metabolic process as a result of yeast supplementation (Kholif and Khorshed, 2006).

Abdel-Salam et al (2014) found that blood concentrations of total protein, albumin, and globulin were greater when lambs received probiotics treatments compared to the control diets.. Also, Mohanna (2000)with growing Frisian calves, Salem et al. (2000) with growing crossbred sheep, and El-Ashryet al.(2003) with Barki lambs, reported that YC supplementation significantly increased plasma globulin values. Hillalet al. (2011) reported that plasma globulin concentration increased significantly $(\mathrm{P}<0.05)$ in growing lambs supplemented probiotics.Soltanet al. (2013) reported that chromium supplementation significantly increased $(\mathrm{p}<0.05)$ blood serum globulin concentration in dairy calves by about $79 \%$ when compared with the control.

On contrast, Mousaet al., (2019) reported that supplementation of probiotics in drinking water did not display differences in plasma TP and A levels between treated and control groups of Barki lambs. Hossein-Ali Arab (2014) 
reported that the supplementation of Bioplus resulted insignificant $(\mathrm{P}>0.05)$ changes in the levels of most of the blood metabolites, total proteins, albumin, glucose, triglyceride while cholesterol level decreased in lambs received 0.5 or $1 \mathrm{~g}$ Bioplus/kg of feed. Also, El-Katchaet al., (2016) and Saleemet al(2016 and 2017) reported that probiotic supplementation in post-weaning lambs diet did not change $(\mathrm{p}>0.05)$ blood constituents of total protein, albumin, globulin and glucose, however blood urea and cholesterol concentrations were significantly decreased with probiotics supplementation $(\mathrm{p}<0.003)$, $(\mathrm{p}<0.04)$, respectively. The decrease in plasma cholesterol level, probably due to microbial feed additives reduced the absorption of lipid from the intestines by de-conjugation (Lubbadehet al., 1999).

\section{Liver and kidney functions:-}

Urea in the blood is an indicator of renal function (Oltner and Wiktorson, 1983). Concerning probiotics supplementation, results in Table (2) indicated that the average values showed that there were significant differences $(\mathrm{P}<0.01)$ in plasma PUN, CHO, TG and GLU concentrations between the two groups where $\mathrm{P}$-calves tended to be has the higher values $(35.62,52.52,35.62$ and $105.7 \mathrm{mg} / \mathrm{dl})$ compared with C-calves (34.54, 47.70, 32.96 and $106.92 \mathrm{mg} / \mathrm{dl}$ ) for PUN, CHO, TG and GLU, respectively. Similarly, Raghebet al. (2003) reported that dietary YS and LS supplementation increased plasma urea concentrations of weaned Frisian calves compared with the control group. Abo El-Nor and Kholif (1998) reported higher blood urea nitrogen values in response to probiotics supplementation. This higher in blood urea nitrogen concentration may be due to incapacity of ruminalmicroflora to detain the ammonia optimally (Butler, 1998).

Juchemet al. (2004) suggested that biological additives, such as monensin or live yeast, were reported to influence blood constituents through remodel of ruminal microbial populations, which was reflected by changes in fermentation end products, i.e. the increase of propionic acid was associated with increased plasma glucose concentration. Abo El-Nor and Kholif (1998) reported higher blood glucose concentration in cows fed diets containing probiotics. Hillalet al. (2011) reported that plasma urea and globulin concentrations increased significantly $(\mathrm{P}<0.05)$ in growing lambs supplemented probiotics. Our results were paralleled with that recorded by Bakret al. (2009). On contract, Moussaet al., (2019) reported that supplementation of probiotics in drinking water did not display differences in plasma urea nitrogen levels between treated and control groups of Barki lambs.

Figure (7) illustrated that plasma concentrations of PUN, CHO and TG followed a pattern which was similar to plasma TP and GL traits whereas P-calves appeared to have higher levels of plasma PUN, CHO and TG than the Ccalves from $\mathrm{D}_{14}$ till $\mathrm{D}_{28}$ post treatment with probiotics while pronounced decrease in both groups occurred at the first week $\left(\mathrm{D}_{7}\right)$ post-weaning. Izuddinet al. (2019) reported that no difference was observed in blood triglycerides and cholesterol levels due to the inclusion of postbiotics from L. plantarum RG14 in newly-weaned lambs. In contrast, Saleemet al (2017) and Bunting et al. (1994) reported that probiotics or chromium picolinate supplementation reduced plasma CHO in weaned lambs and growing Holstein calves, respectively.

Ding et al. (2008) reported that plasma urea-N concentration was decreased $(\mathrm{p}<0.05)$ of male weaned lambs by Monensin and live yeast supplementations. Sayed (2003) reported no significant effect of probiotics supplementation on PUN in goat's kids. Ghoneem and Mahmoud. (2014) reported that no significant differences in plasma triglycerides concentration $(\mathrm{P}>0.05)$ with Barki lambs fed in-activated and dried yeast. Beaucheminet al. (2003) did not observe any change in GLU concentration with yeast supplementation in cattle. On the contrary, Antunovicet al., (2005 and 2006) and Dimovaet al. (2013) reported that lambs supplemented probiotics had lower levels of urea in the blood, indicating a better utilization of nitrogen from diet. On the other hand, the lower level of blood urea, probably due to better utilization of nitrogen from diet in the rumen with probiotic supplementation (Saleemet al 2017). 

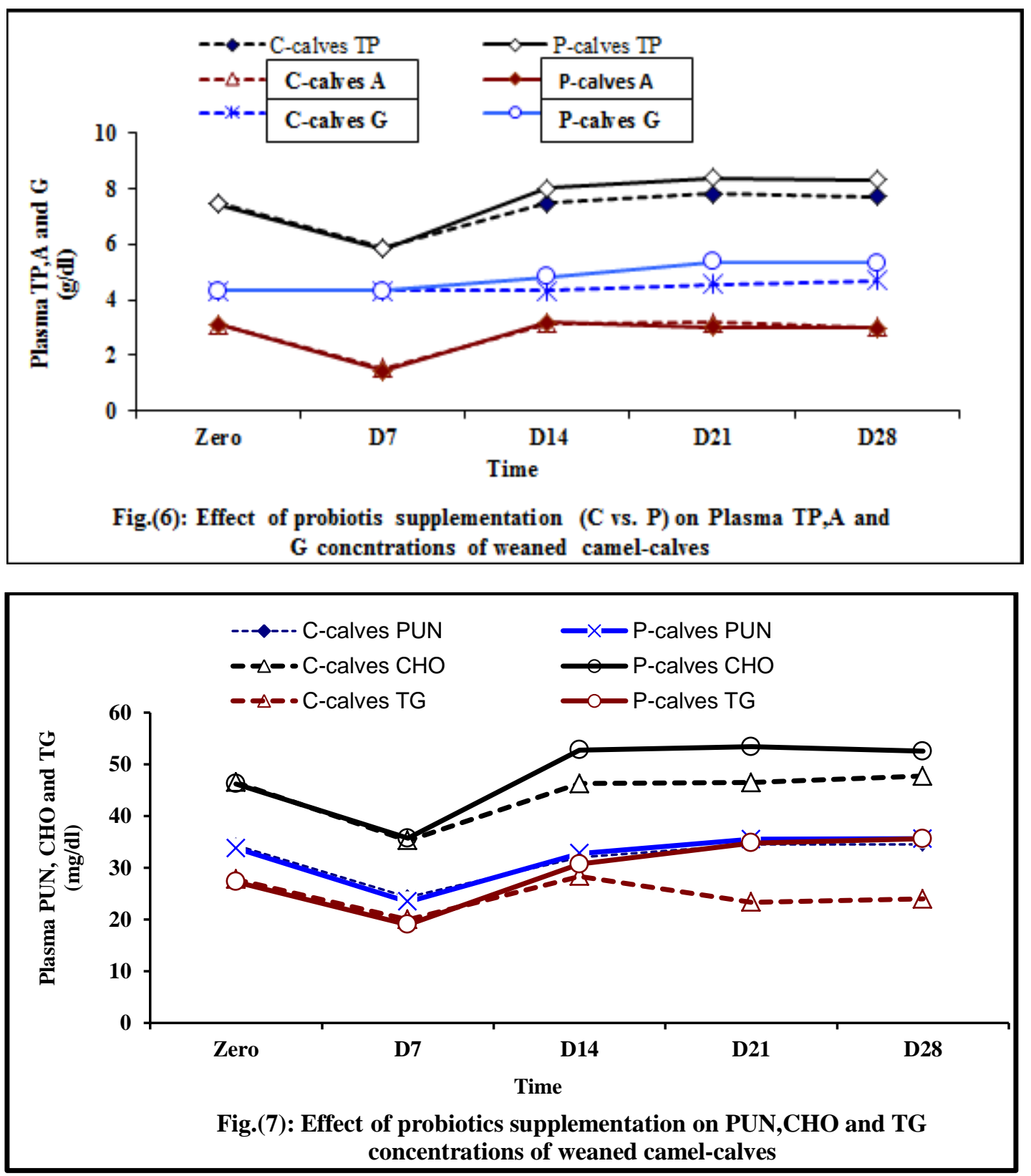

Statistical analysis stated that there is a significant increase $(\mathrm{P}<0.01)$ in plasma glucose concentration in both groups but P-calves was had the higher levels, this result may be related to rapid rate of hydrolysis and absorption of the dietary carbohydrates in alimentary tract that may be resulted from the effect of probiotics on activity of amylase which lead to increase carbohydrates hydrolysis in the small intestine (Abdel-Khaleket al. 2000). Otherwise, this may be attributed to increase the activity of cellulolytic bacteria that act on cellulose fibers degradation and thus produced more glucose and increased the glucogenic precursor propionate in rumen or decreased plasma insulin and insulin glucose ratio leading to an increase in gluconeogenesis (Dawson, 1993).

\section{Enzymes activity response:-}

Concerning the effect of probiotics on plasma enzymes levels, results presented in Table (2) indicated that the overall of plasma enzymes levels were similarly for both control and supplemented with probiotics groups $(10.56,29.6,81.30$ and 474.1 vs. $10.60,30.30,81.10$ and $473.9 \mu / 1)$. Thus, no significant effect registered for probiotics supplementation on any enzyme measured, Similarly, Mousaet al., (2019) reported that supplementation of probiotics in drinking water did not display differences in plasma ALT and AST levels between treated and 
control groups of Barki lambs. Soltanet al. (2013) reported that there were no significant differences in ALT and AST levels between control and supplemented lambs with probiotics. Abdallaet al. (2013) reported that plasma AST and LDH activities are insignificantly changed in buffalo calves post treatment with Saccharomyces cerevisiae. Doležalet al. (2011) said that AST and LDH concentrations are apparently not connected with the yeast culture supplementation but rather with the diet and with the individuality of cows. Also Abdel-Khaleket al. (2000) reported that value of serum AST was not significantly affected by using yeast treatments with suckling Frisian cows. Ghoneem and Mahmoud. (2014) reported that no significant differences in plasma ALT and AST concentrations $(\mathrm{P}>0.05)$ with Barki lambs fed inactivated and dried yeast. Hillalet al. (2011) reported that no significant differences were observed in ALT and AST levels between controls and supplemented growing lambs with probiotics. On the contrary, Kassabet al.,(2017) reported that supplementation of probiotics in the diet of beef bulls increased significantly levels of ALT, AST, thyroxin and tri-iodothyronine hormones for treated groups compared with control group.

Figure (8) illustrated that ALT, AST and ALP levels decreased significantly $(\mathrm{P}<0.05)$ on $\mathrm{D}_{7}$ followed by rapidly increase from $\mathrm{D}_{14}$ till the end of study $\left(\mathrm{D}_{28}\right)$ with identical values in both groups, this suggests that the shifting from liquid to solid diets stressor (weaning) short lived (may be less than 14 days period) and this behavior reflect reestablishment of the cellular homeostasis in liver and the adaptability of calves to post-weaning conditions. Aida et al. (2008) found that the levels of serum AST, ALP levels were significantly increased $(\mathrm{P}<0.05)$ in treated groups with antibiotics compared to controls in growing buffaloes' calves. LDH enzyme behaved the opposite trend on $\mathrm{D}_{7}$ and behaved the same trend of the other enzymes with similar values between both groups. These findings indicating all calves had become adapted to the solid feeds without any adverse effect on animal health.

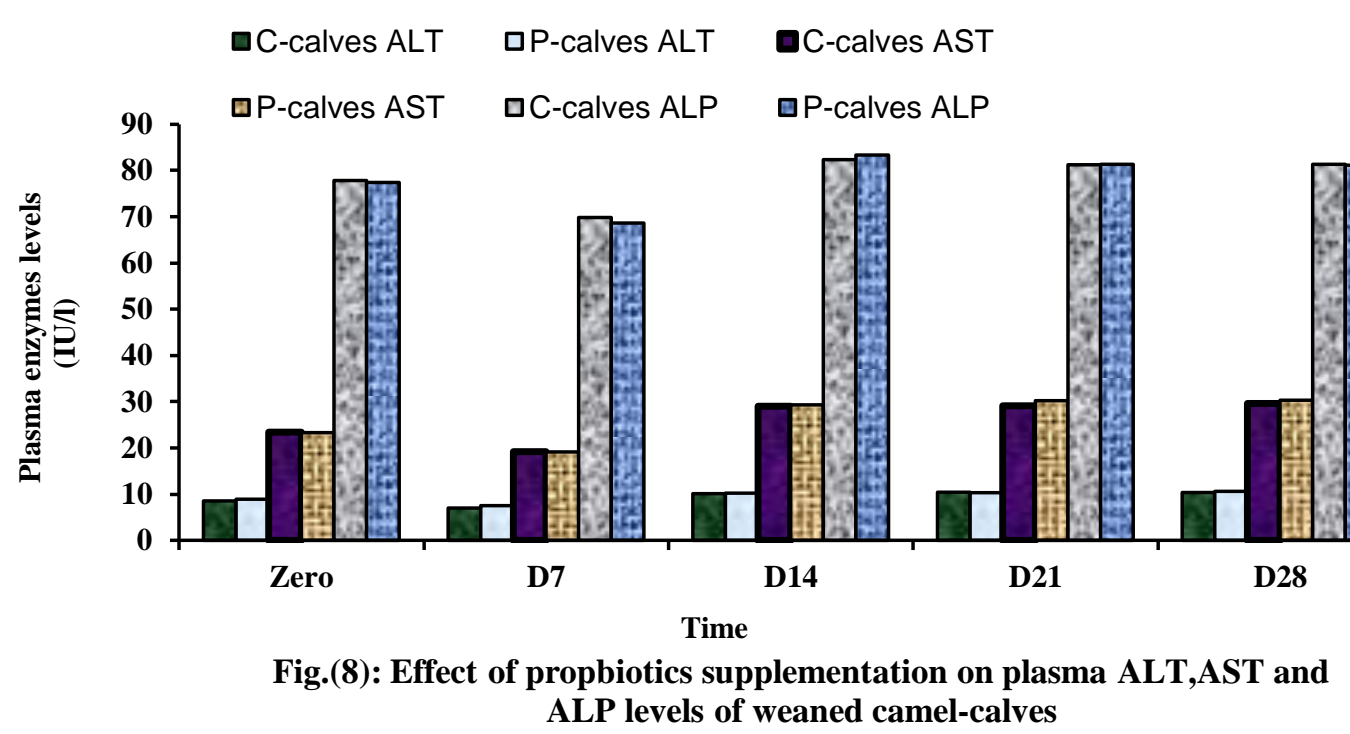

Thyroid hormones response:-

With respect the effect of probiotics on circulatory $T_{3}$ and $T_{4}$ levels, results in Table (2) indicated that there was no significant treatment effect on values of plasma $\mathrm{T}_{3}$ and $\mathrm{T}_{4}$ concentrations for C-calves (2.57 and 165.1) compared with P-calves $\left(2.56 \mathrm{ng}^{-1} \mathrm{dl}\right.$ and $\left.164.9 \mu \mathrm{g}^{-1} \mathrm{dl}\right)$. In accordance, Estellet al. (1993) found that no beneficial effect $(\mathrm{P}>0.10)$ of supplementing Se yeast on thyroid hormone concentrations of the calf during post-weaning.

Kassabet al., (2017) reported that supplementation of probiotics in the diet of beef bulls increased significantly levels thyroxin and tri-iodothyronine hormones for treated groups compared with control group, the increase in the secretion of the thyroid hormones may be due to: 1- The increase of carbohydrate, fat and protein metabolism 2The increase of TDN intake as an indicator for energy metabolism. Also, the increase in the thyroid hormones secretion may be due to there was a positive relationship between energy intake and the concentration of the thyroid hormones as it was reported in literature by Ahmed,2003; Kassab, 2007; Toshihiro 2010; Zanouny ,2011 and Kassab and Hamdon, 2014. 


\section{Conclusion:-}

Concerning management at weaning process the most important factors which might affect the physiological responses is either allows the attachment between calves and their dams for two weeks at least during post-weaning period. Adaptation to separation calves from their dams was pronounced at the $2^{\text {nd }}$ week post-weaning on all biochemical parameters where calves and their dams gradually becoming more independent of one another. With few exceptions of plasma $\mathrm{T}_{3}$ and $\mathrm{T}_{4}$ levels, which were relatively lower levels of CSS-calves and I-calves groups compared with CCS-calves and G-calves. These findings were reflected distress associated with psychological stress during the first two weeks following weaning. In addition, supplementation of probiotics can have small or of minor importance on $\mathrm{T}_{3}$ and $\mathrm{T}_{4}$ levels with sampling time progress. The results of the present study suggest that plasma parameters across the experimental period describe changes in the nutritional conditions as a result of the transition from liquid to solid feed in association with weaning process.

\section{Acknowledgements:-}

The researchers acknowledge the farm staff working at animal production sector, Maryout Research Station for their assistance with animal handling and management. It would have been very difficult to conduct this work without their positive cooperation. We gratefully thanks to Dr Samir El-Sheikh, researcher professor in Animal Breeding Department, for his help in statistical analysis. Finally, we gratefully thank to the late Abdel-Fattah Rashed for his cooperation on analysis of animal diets.

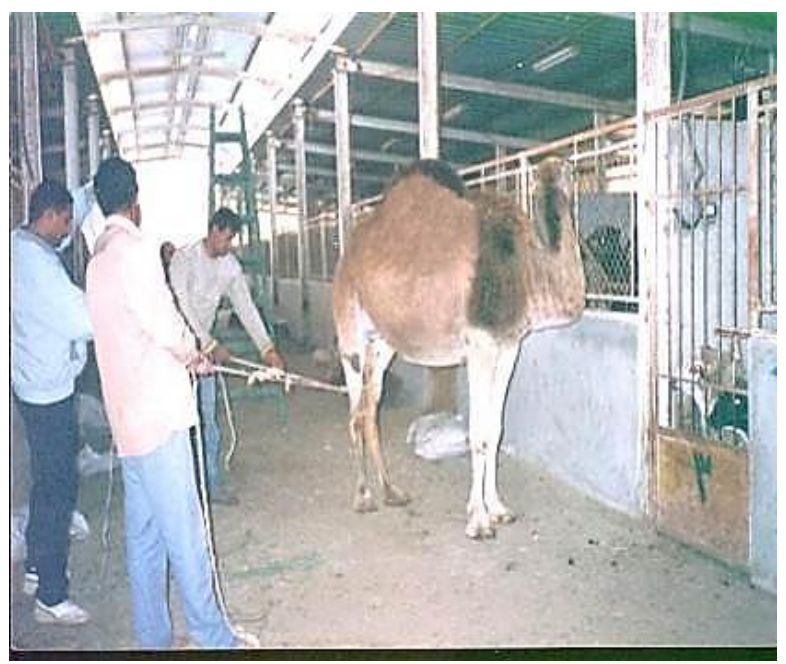

Picture 1:-The first step of anti-suckling preparation.

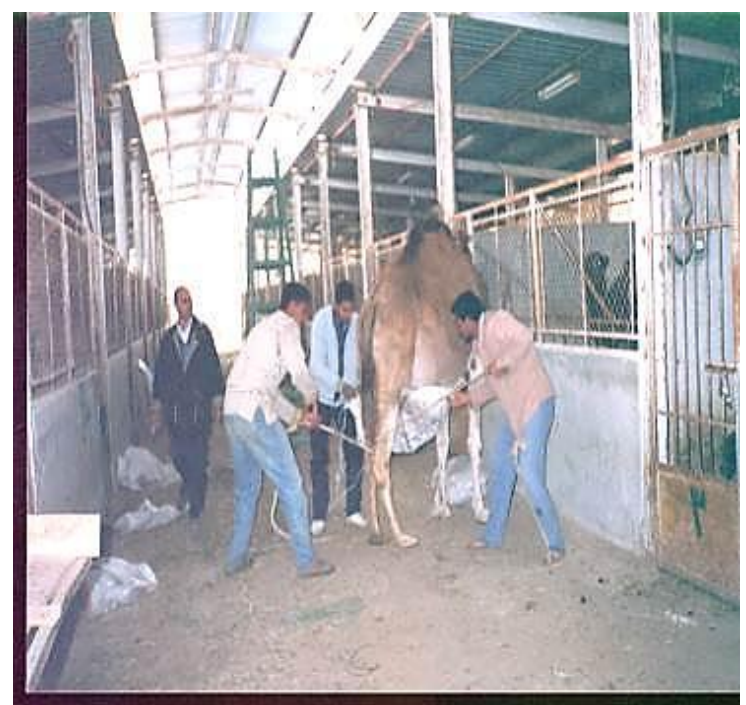

Picture 2:- The second step of anti-suckling preparation. 


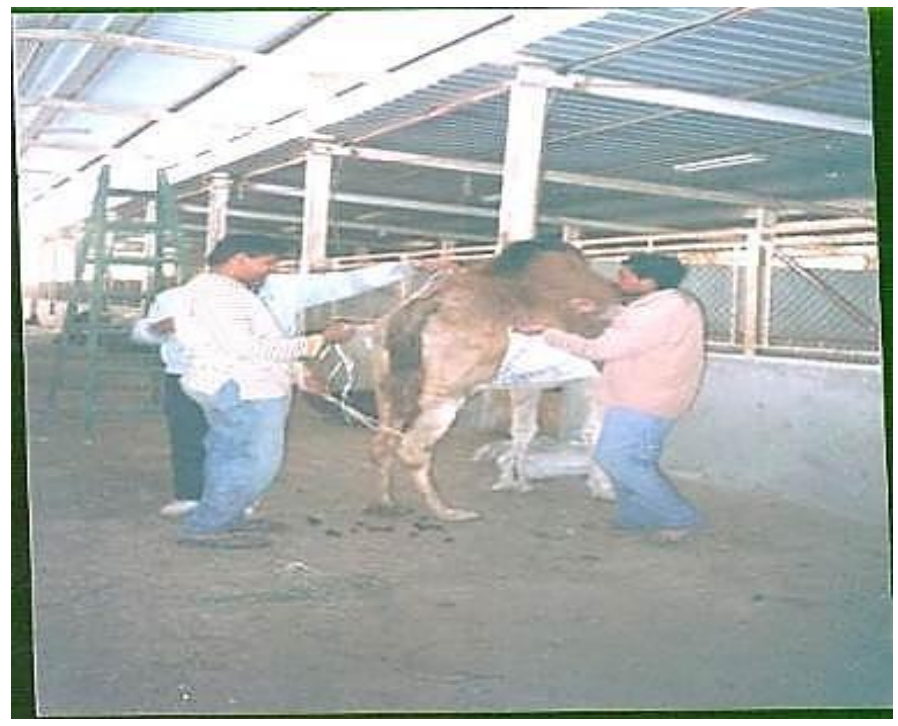

Picture 3:- The final step of anti-suckling preparation

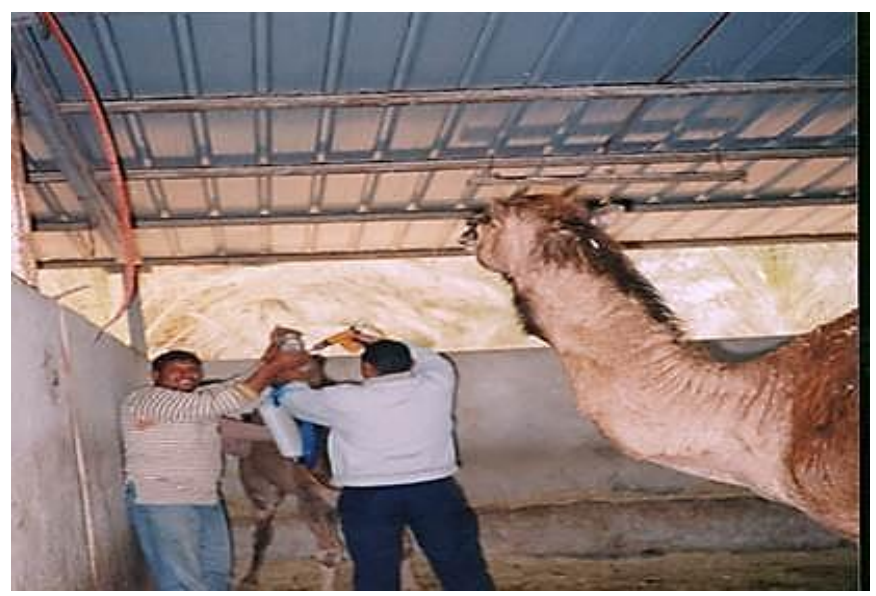

Picture 4:- Completely contact system (she-camel with their calf) housed individually and supplemented with probiotics, $20 \mathrm{~g} / \mathrm{h} / \mathrm{d}$.

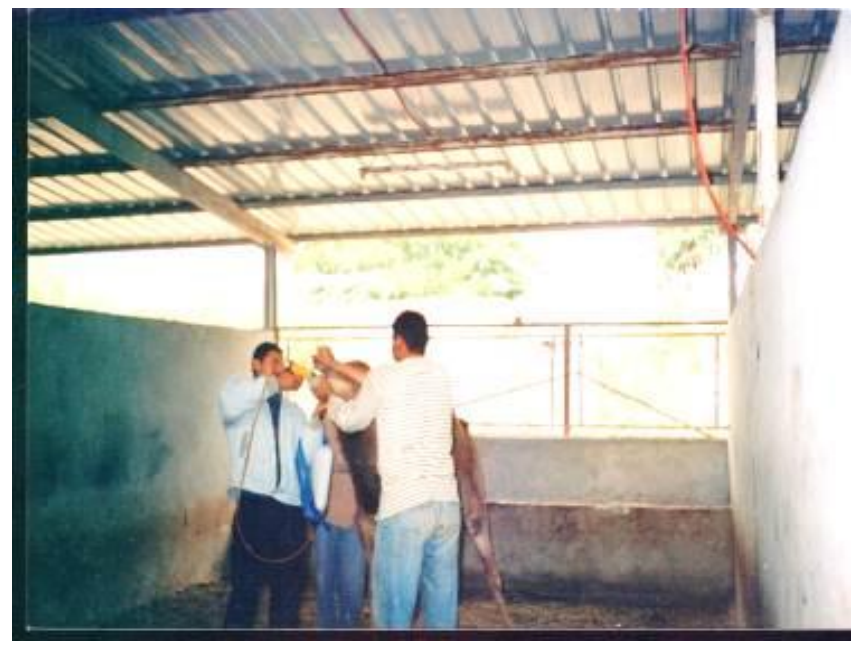

Picture 5:- Completely separation system (camel-calve housed individually and supplemented with probiotics, $20 \mathrm{~g} / \mathrm{h} / \mathrm{d})$. 


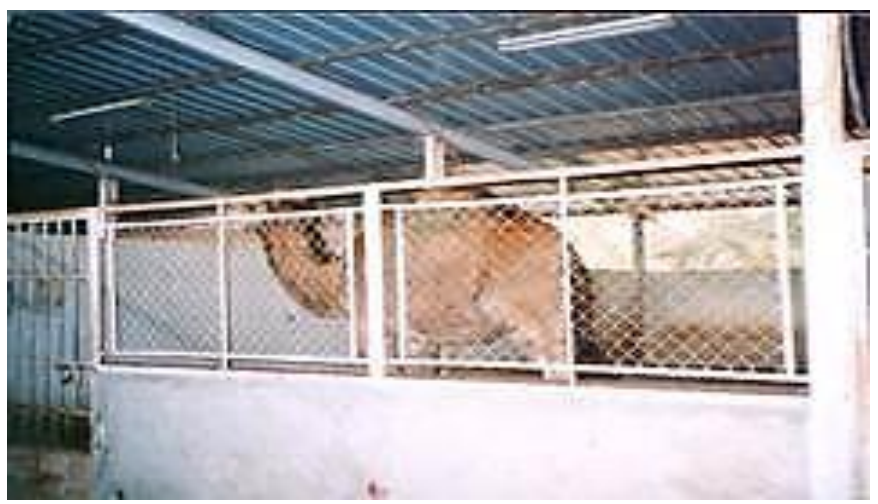

Picture 6:- Completely separation system (camel-calve housed individually and un-supplemented with probiotics).

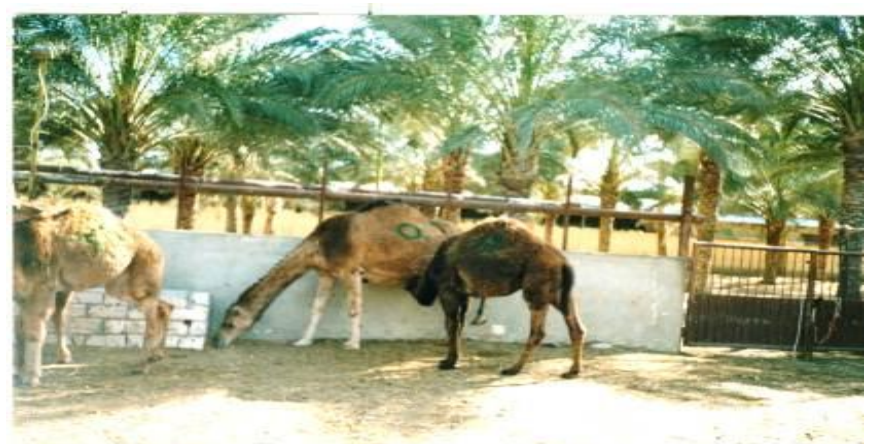

Picture 7:- Completely separation system (camel-calves housed in group and supplemented with probiotics, $20 \mathrm{~g} / \mathrm{h} / \mathrm{d})$.

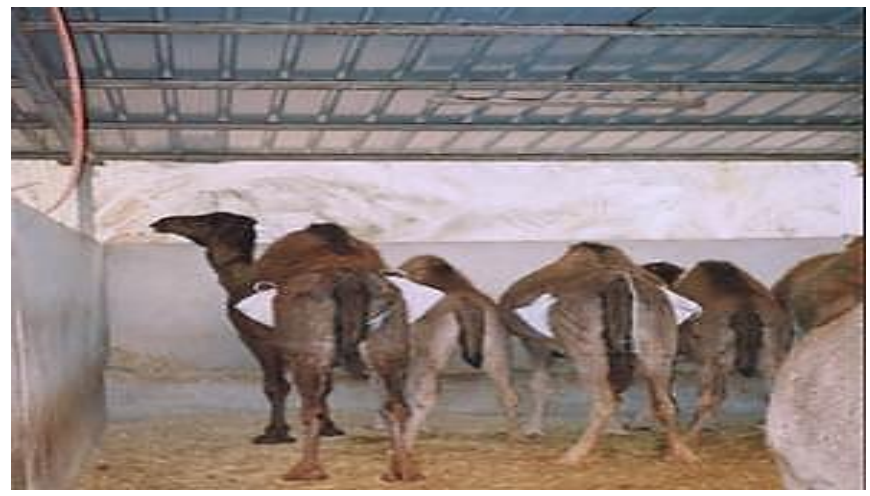

Picture 8:- Completely contact system (camel-calves housed in group and un-supplemented with probiotics).

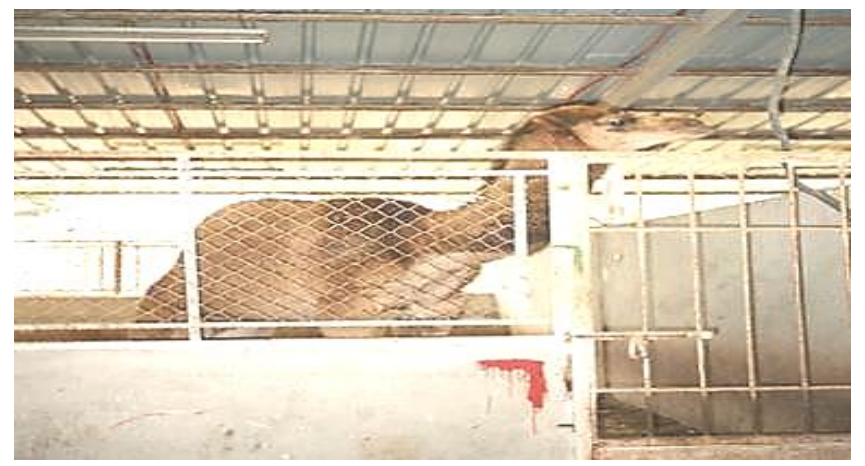

Picture 9:- Completely separation system (camel-calve housed individually and un-supplemented with probiotics. 


\section{References:-}

1. Abd-Allah M. , M.Y. Elaref and A.I.Zanouny 2015. Influence of different managerial systems on performance and physiological responses of developing buffalo calves during fattening period. Egyptian J. Anim. Prod. 52(1):1-9.

2. Abdalla,O.A., E.EL-BoshyM.,Abdel Hamid Fatma M. and Ali, Nosa M. 2013. Clinicopathological studies of dietary supplementation of Saccharomyces cerevisiae in calves. Journal of American Science, (9):298-306.

3. Abdel-Khalek AE, Mehrez AZ and Omar AM. 2000. Effect of yeast culture (Yea Sacc) on rumen activity, blood constituents and growth of suckling Frisian cows. Proceeding of the conference on Anim.prod. in the 21 st Century, Sakha, Kafr El-Sheikh, (18-20April).

4. Abdel-Salam A.M., M. M. Zeitoun and M.M. Abdelsalam 2014. Effect of synbiotic supplementation on growth performance, blood metabolites, insulin and testosterone and wool traits of growing lambs. J BiolSci; 14:292298.

5. Abdul-Rahman, II, Chikpah, SK and Yaro, M. 2012. Response of Djallonke lambs to repeated separation from their dams during the first week of lactation: 2. Physiological response, J. of Anim. Prod. Advances vol.2 (12):527-532.

6. Abo El-Nor SAH, Kholif MA. 1998. Effect of supplementation of live yeast culture in the diet on the productive performance of lactating buffaloes. Milchwissenschaft, 53: 663-666.

7. Ahmed, S. K. .S. 2003. Studies on energy and protein allowances in ration for pregnant and milk producing buffaloes. Ph.D. Thesis, Fac. Agric., Ain Shams University. Egypt.

8. Aida M.A. Ahmed; Ahmed, A. A. and Nani, S. Ebrahim 2008. Serum biochemical and immunological alterations due to prophylactic use of antibiotics in growing buffaloe calves. Egypt. J. Comp. Path. \& Clinic. Path. Vol. 21 No. 2 (April); 231 - 246.

9. Ali M.H., M.A. Norouzian and A.A. Khadem 2015. Performance and measures of stress in lambs weaned at 45 and 90 days. Iranian J. of Applied Anim. Scie. 5,(4):981-985.

10. Antunovic, Z., M. Speranda, B. Liker, V. Seric, D. Sencic, M. Domacinovic and T. Speranda, 2005. Influence of feeding the probiotic pioneer to growing lambs on performances and blood composition. Acta Vet., 55: 287300 .

11. Antunovic, Z., M. Speranda, D. Amidzic, V. Seric, Z. Steiner, N. Doma-Cinovic and F. Boli, 2006. Probiotic application in lamb's nutrition. Krmiva, 4: 175-180.

12. AOAC. 2005 Official methods of analysis association of Analytical chemists, 16th ed. Aoac. International, Washington, DC., USA.

13. Apple, J. K. Kegley, E. B. Galloway, D. L. Wistuba, T. J. and Rakes L. K. 2005. Duration of restraint and isolation stress as a model to study the dark-cutting condition in cattle. J. Anim. Sci., 83:1202-1214.

14. Apple, J. K., J. E. Minton, K. M. Parsons, and J. A. Unruh. 1993. Influence of repeated restraint and isolation stress and electrolyte administration on pituitary-adrenal secretions, electrolytes, and other blood constituents of sheep. J. Anim. Sci. 71:71-77.

15. Atasoglu C, Yurtman I.Y., Savas T., Gultepe M. and Özcan, Ö. 2008. Effect of weaning on behavior and serum parameters in dairy goat kids. Anim. SCi., J. Vol.79 (4): 435-442.

16. Babu LK, Pandey H. ,Patra TC. and Sahoo A. 2009. Hemato-biochemical changes, disease incidence and live weight gain in individual versus group reared calves fed on different levels of milk and skim milk. Anim. Sci., J. Apr.; 80(2):149-156.

17. Bakr, H.A., Said, E.M., Abd El-Tawab M.M., and Hassan, M.S., 2009. The impact of probiotic (Biovet $\left.{ }^{8}\right)$ on some clinical, hematological and biochemical parameters in buffalo-calves. Beni-Suef Veterinary Medical journal 19:1-10.

18. Beauchemin, K.A., W.Z. Yang, D.P. Morgavi, G.R. Ghorbani, W. Kautz and J.A. Leedle. 2003. Effects of bacterial direct-fed microbials and yeast on site and extent of digestion, blood chemistry and subclinical ruminal acidosis in feedlot cattle. J. Anim. Sci., 81:1628-1640.

19. Bueno, A, Todd C, Chuck S, Rasby, RJ. ,Clemens, E and Dragastin, M.1998. Evaluating stress in calves weaned at three different ages. Nebraska Beef Cattle Reports. Paper 326. pp. 21-26. http://digitalcommons.unl.edu/animalscinbcr/326.

20. Bunting, L.D., Fernandez, J.M. , Thompson, D.L.Jr. and Southern, L.L. 1994. Influence of chromium picolinate on glucose usage and metabolic criteria in growing Holstein calves. J. Anim. Sci., (72):1591-1599.

21. Butler WR. 1998. Review: Effect of protein nutrition on ovarian and uterine physiology in dairy cattle. J. Dairy Sci., 81: 2533-2539.

22. Casamassima D., Sevi A., Palazzo M., Ramacciato R., Colella G.E., Belitti A. 2001. Effects of two different housing systems on behavior, physiology and milk yield of Comisana ewes. Small Rum Res, 41, 151-161. 
23. Chibsa M.B., Yesihak Y.M., Mohamed Y.K. and Leta M.U. 2014. Defining weaning age of camel calves in Eastern Ethiopia. Springer Plus. 2014, (3):1-5.

24. Coppo, J.A. 2000. Impacto del desteteprecozsobre el mediointerno de terneroscruzacebŭ. Tesis de Doctorado, FacultadCienciasCieniasVeterinarias, Universidad NacionaldelNordeste, Corrientes, Argentina.

25. Coppo, J.A. 2001. Evolution of fructosaminaemia and glucaemia during the growth of un-weaned and early weaned half-bred Zebu calves. Vetrinary Research Communications, 25, pp.449-459.

26. Coppo, J.A., Mussart, N.B., Revidatti, M.A. and Capellari, A. 2003. Absence of biochemically demonstrable stress in early weaned half-bred Zubu calves. Cien. Inv. Agr. 30(2):97-105.

27. Davis, C. L., and J. K. Drackley. 1998. The Development, Nutrition and Management of the Young Calf. Iowa State Press, Ames.

28. Dawson KA.1993. Biotechnology in the feed industry. Proc. of Alltechs 9th Annual Symp. T.P. Lyons,Ed.Alltech's Technical Publications; 296.

29. Dimova, N.; M. Baltadjieva, V. Karabashev, S. Laleva, Y. Popova, P. Slavova, J. Krastanov and G. Kalaydjiev. 2013. Effect of supplementation of probiotic Zoovit in diets of calves of milk breed. Bulgarian Journal of Agricultural Science, 19 (Supplement 1), 94-97.

30. Ding J, Zhou ZM, Ren LP, Meng QX. 2008. Effect of Monensin and live yeast supplementation on growth performance, Nutrient digestibility, carcass characteristics and ruminal fermentation parameters in lambs fed steam-flaked corn-based diets. Asian-Aust. J. Anim. Sci., 21: 547- 554.

31. Doležal1 P, Jan D, Doležal1 J, Čermáková1 J, Zeman L and KatarzynaS.2011 Effect of feeding yeast culture on ruminal fermentation and blood indicators of Holstein dairy cows, Acta Vet. Brno., 80: 139-145.

32. Duncan, D.B. 1955. Multiple range and multiple F-test. Biometrics. 11:1-42.

33. Dvorak M and M Neumannova, 1986. Effects of stimulated adrenocortical activity on the concentration of thyroxin and triiodothyronine in blood serum of piglets. ClinEndocrinol, 88: 339-345.

34. Early, B. and McGee, M. 2011. Examination of the effect of weaning stress on physiological, immune and behavioral responses of beef calves. Technology Update, animal \& Grassland Research and innovation, Project number: 5742. <http://www. teagasc.ie/publications/2011/1319/Weaning-stress-on-beef-calves_5742.pdf.

35. El-Ashry MA, Fayed AM, Youssef KM, Salem FA, Hend AA. 2003. Effect of feeding flavomycin or yeast as feed supplement on lamb performance in Sinai. Egypt J Nutr Feed 6 (Special Issue), 1009-1022.

36. El-Katcha, M. I., M. A. Soltan and M. S. Essi 2016. Effect of Pediococcus spp. supplementation on growth performance, nutrient digestibility and some blood serum biochemical changes of fattening lambs. Alex. J. Vet. Sci., 49:44-54.

37. Esonu, B.O., Enenalom, O.O., Udedibie, A.B.I., Herbert, U., Ekpor, C.F., Okoli, I.C. and Iheukwumere, F.C. 2001. Performance and blood chemistry of weaner pigs fed raw mucuna (velvef bean) meal. Trop. Anim. Prod. Invest., 4: 49-55.

38. Estell, R.E.; Havstad, K.M.; Heird, C.E.; Fredrickson, E.L. ;Hallford, D.M. and Shupe, W.L. 1993. Effects of repeated cycles of feed intake shifts on growth, feed efficiency and endocrine profiles of wether lambs. Smaal Ruminant Research, 10: 103-118.

39. Faturi, C.B.; Tiba, P.A.; Kawakami, S.E.; Catallani, B.; Kerstens, M. and Suchecki, D. 2010. Disruptions of the mother-infant relationship and stress-related behaviours: Altered corticosterone secretion does not explain everything. Neurosci. Biobehav. Rev., 34, 821-834.

40. Fazio E, Medica P, Cravana C, Messineo C, Ferlazzo A. 2007.Total and free iodothyronine levels of growing Thoroughbred foals: effects of weaning and gender. Livestock Sci. 110:207-213.

41. Fazio E., A. Ferlazzo, C. Cravana and P. Medica 2015. Effects of weaning on total and free iodothyronines in lambs, Veterinary Quarterly, 35:1, 16-20.

42. Friend TH, Dellmeier GR, Gabur EE. 1985. Comparison of four methods of calf confinement. I. Physiology. Journal of Animal Science 60, 1095-1101.

43. Ghoneem, Wafaa M. A. and Mahmoud, A.E.M. 2014. Effects of in-activated and dried yeast on productive performance of Barki lambs. Asian J. of Anim. and Vet. Advanc.,1-10.

44. Gibert, P. 1991. Conse 'quences de la capture et des manipulations sur la physiologie des ongule'ssauvages. Incidence pathologique. Bilanetconaissances. Bulletin Mensuel de l'Office National de la Chasse 161: 31-40.

45. Gulliksen, S.; Jor, E. ; Lie, K.I. ; Loken, T. Akerstedt, J. and Osteras, O. 2009. Repiratory infections in Norwegian dairy calves. American Dairy Science Association, 92, 5139-5146.

46. Haley, D.B.; Bailey, D.W. and Stookey, J.M. 2005. The effects of weaning beef calves in two stages on their behavior and growth rate. J. Anim. Sci., 83, 2205-2214.

47. Hammon, H. M., and J. W. Blum. 1998. Metabolic and endocrine traits of neonatal calves are influenced by feeding colostrum for different duration or only milk replacer. J. Nutr. 128:624-632. 
48. Hickey, M., M. Drennan, and B. Earley. 2003. The effect of abrupt weaning of suckler calves on the plasma concentrations of cortisol, catecholamines, leukocytes, acutephase proteins and in vitro interferon-gamma production. J. Anim. Sci. 81:2847- 2855.

49. Hillal H., El-Sayaad G. and Abdella M. 2011. Effect of growth promoters (probiotics) supplementation on performance, rumen activity and some blood constituents in growing lambs. ArchivTierzucht 54 (6), $607-617$.

50. Hossein-Ali Arab, A. Mashhadi-Esmaeil, M. Reazian and M. Mohtasebi 2014. Effects of Bacillus subtilis and Bacillus licheniformis based on probiotic on performance, hematological parameters and blood metabolites. Vol.3, Issue (4):8-15.

51. Izuddin W. I., Loh T. C., Samsudin A. A., Foo H. L., Humam A. M. andShazali N. 2019. Effects of postbiotic supplementation on growth performance, ruminal fermentation and microbial profile, blood metabolite and GHR, IGF-1 and MCT-1 gene expression in post-weaning lambs. BMC Veterinary Research, 15:1-10.

52. Juchem, S. O., F. A. P. Santos, H. Imaizumi, A. V. Pires and E. C. arnabé. 2004. Production and blood parameters of Holstein cows treated prepartum with sodium monensin or propylene glycol. J. Dairy Sci. 87:680689.

53. Kassab, A. Y. and H. A. Hamdon 2014. Effect of anabolic androgenic synthetic steroid (boldenoneundecylenate) on productive performance and some blood parameters of beef bulles. Egypt. J. Nutr. and Feeds, 17 (2): 225-236.

54. Kassab, A. Y., Hamdon H. A. and Mohammed A. A. 2017. Impact of probiotics supplementation on some productive performance, digestibility coefficient and physiological responses of beef bulls under heat stress conditions. Egyptian J. Nutrition and Feeds, 20(1): 29-39.

55. Kassab, A.Y.M. 2007. Effect of protected protein on productive and reproductive performance of Sohagi sheep. Ph.D. Thesis, Faculty of Agriculture El-Minia University, Egypt.

56. Katunguka RE, Larkin H. and Kelly WR. 1987. Blood values of neonatal calves and blood values and live weight gains of calves fed on different levels of milk replacer. British Vet. J. 143, 184-190.

57. Kholif, S.M. and Khorshed, M.M. 2006. Effect of yeast or selenized yeast supplementation to rations on the productive performance of lactating buffaloes. Egypt. J. Nutr. Feeds, 9:193-205.

58. Komonna OF. 2007. Physiological and nutritional responses of sheep to some feed additives. Ph.D. Thesis,Fac. Agric., Minufiya University.

59. Lee HJ, Khan MA, Lee WS, Kim HS, Ki KS, Kag SJ, Hur TY, Khan MS and Choi YJ. 2008. Growth, blood metabolites, and health of Holstein calves fed milk replacer containing different amounts of energy and protein. Asian-Australas J. Anim. Sci., 21:198-203.

60. LeNeindre, P. 1993. Evaluating housing systems for veal calves. J. Anim. Sci. 71:1345-1354.

61. Lubbadeh W, Haddadin MSY, Al-Tamimi MA, Robinson RK. 1999 Effect on cholesterol content of fresh lamb of supplementing the feed of Awassiewes and lambs with Lactobacillus acidophilus. Meat Sci;52:381-385.

62. Lynch EM, Earley B, McGee M, Doyle S. 2010. Characterization of physiological and immunological responses in beef cows to abrupt weaning and subsequent housing. BMC Vet Res, 6(1), 37:1-8.

63. Maccari P., S. Wiedemann, H.-J. Kunz, M. Piechotta, P. Sanftleben, M. Kaske 2014. Effects of two different rearing protocols for Holstein bull calves in the first 3 weeks of life on health status, metabolism and subsequent performance. J. of Anim. Physiol. And Anim. Nutr.Vol. 99, Issue (4):737-746.

64. Macro I. ;Vinas L. ; Velardi R. ; Pastor J. and Lavin S. 1997. Effects of capture and transport on blood parameters in free-ranging mouflon (ovisammon). J. of Zoo and Wildlife Medicine 28(4):428-433.

65. Mal M.E., Friend T.H., Lay D.C., Vogelsang S.G. and Jenkins O.C.1991. Physiological responses of mares to short term confinement and social isolation. J. of Equine VetrinaryScienceVolume 11, Issue 2, 96-102.

66. Mohanna AA. 2000. The use of non-hormonal growth enhances with different nutritional levels for growing Friesian calves until slaughter. M Sc Thesis, Faculty of Agriculture, Ain Shams University, Cairo, Egypt.

67. Montane' J. , Marco I. , Lo' pez-Olvera J., Perpiña'n D., Manteca X., and Lavi'n S. 2003. Effects of acepromazine on capture stress in Roe Deer (capreoiuscapreoius). Journal of Wildlife Diseases, 39(2), 2003, pp. 375-386.

68. Möstl, E. and Palme, R. 2002. "Hormones as indicators of stress” Domestic Animal Endocrinology, vol. 23, pp67-74.

69. Mousa KH, El-Malky OM, Komonna OF, and Rashwan SE. 2012. Effect of some yeast and minerals on the productive and reproductive performance in ruminants. J. of American Sci.;8 (2): 291-303.

70. Mousa S., Elsayed A., Marghani B. and Ateya A. 2019. Effects of supplementation of Bacillus spp. on blood metabolites, antioxidant status, and gene expression pattern of selective cytokines in growing Barki lambs. J. Adv. Vet. Anim. 6(3):333-340. 
71. Niezgoda J, Bobek S, Kmiecik A, Wronska-Fortuna D, 1993. Neonatal sympatho-adrenal and pituitary-adrenal cortex axis responses to stress in lambs. Book of Abstracts ESNA. Halle, Germany: 58.

72. Niezgoda, J., D. Wronska, K. Pierzchala, S. Bobek, and S. Kahl. 1987. Lack of adaptation to repeated emotional stress evoked by isolation of sheep from the flock. J. Vet. Med. 34A734.

73. Oler A. and Glowinska B. 2013. Blood chemistry, thyroid hormones, and insulin serum content in bulls fed a ration limited in energy. Turk J Vet Anim Sci., 37: 194-199.

74. Oltner, R. and H. Wiktorsson, 1983. Urea concentrations in milk and blood as influenced by feeding varying amounts of protein and energy to dairy cows. Livest. Prod. Sci., 10: 457-467.

75. Orgeur, P., Bernard, S. Naciri M., Nowak R. Schaal, B. and Levy, F. 1999. "Psychological consequences of two different weaning methods in sheep", Reproduction Nutrition Development, vol 39, pp.231-244.

76. Orihuela, A. and Galina C. 2019. Effects of separation of cows and calves on reproductive performance and animal welfare in tropical beef cattle. Animals (9),223,pp.1-13. doi:10.3390/ani9050223.

77. Pérez, L.I.; Orihuela, A.; Galina, C.S.; Rubio, I.; Corro, M.; Cohen, A. and Hernández, A. 2017. Effect of different periods of maternal deprivation on behavioral and cortisol responses at weaning and subsequent growth rate in zebu (Bosindicus) type cattle. Livest. Sci. 197, 17-21.

78. Pierzchała K, Niezgoda J and Bobek S. 1985 The effect of isolation on plasma cortisol, glucose and free fatty acids in sheep. ZentralblVeterinarmed A. 1985;32(2):140-145.

79. Putnam DE and Schwab CG. 1994. Mode of action of yeast culture. J. Anim. Sci.;72: $2-5$.

80. Ragheb EE, Mehriz AF, Abdel-Khalik AE. 2003. Digestibility coefficients, blood parameters, feed efficiency and growth performance of weaned Frisian calves fed diet supplemented with lacto-sacc. Egypt J Nutr Feed 6 (Special Issue), 693-702.

81. Reitman, S. and Frankel, S. 1957. "A colormetric method for the etermination of serum glutamic oxaloacetic and glutamicpyruvic transaminase.” Am. J. Clin. Path., 28: 56-63.

82. Roy, A.V. 1970. "Rapid method for determining alkaline phosphatase activity in serum with thymolphthalein monophosphate." Clin. Chem., 16 (5):431-436.

83. Saleem, A. M., A. I. Zanouny, A. M. Singer 2017. Growth performance, nutrients digestibility, and blood metabolites of lambs fed diets supplemented with probiotics during pre- and post-weaning period. Asian- Australasian J. of Anim. Sci., 30:1-8.

84. Saleem, A. M., and A. I. Zanouny 2016. Effect of two levels of probiotics supplementation on performance, digestibility and some blood constituents in weaned lambs. Egypt. J. Nutr. and Feeds, 19 (2): 265-275.

85. Salem FA, Soliman AS, Abd El-Mawla SM, El-Mahdy MR. 2000. Effect of some feed additives added to diets of growing sheep on performance, rumen fermentation, blood constituents and carcass characteristics. Benha University, Egypt, Ann AgricSciMoshtohor 38, 1885-1904.

86. SAS Institue 2008. SAS/STAT software version 9.2 SAS Institute, Inc., Cary. N.C.,USA.

87. Sayed, A.S. 2003. Studied on the influence of pronifer as a probiotics on the clinical, hematological and biochemical status of the goat's kids. Assiut Vet. Med. J. 99:131-143.

88. Soltan M.A., Almujalli A.M., Mandour M.A. and El-ShinwayAbeer M. 2013. Effect of dietary chromium supplementation on growth performance, rumen fermentation characteristics and some blood serum units of fattening dairy calves under heat stress. Pakistan Journal of Nutrition 11 (9): 751-756.

89. Stehulova, I., Lidfors, L. and Spinka, M. 2003. Response of dairy cows to separation from calves: Effects of calves' age and visual/auditory contact. In: 37th International Congress of the International Society for Applied Ethology (Eds: Ferrante, V.). Edito a Cura Della, AbanoTerme, Italy, pp. 163.

90. Stull, C. and Reynolds, J. 2008. Calf Welfare. Vet. Clin. Food Anim., 24, 191-203.

91. Terré M., Bach A. and Devant M. 2006. Performance and behaviour of calves reared in groups or individually following an enhanced-growth feeding programme. Journal of Dairy Research, Vol. 73 :(4), pp 480-486.

92. Toshihiro, I. 2010. Thyroid hormone and atherosclerosis. VascPharmacol. Mar-April, 52(3-4):151-156.

93. Wronska D., Niezgoda, J. A Sechman, A. and Bobek S. 1990. Food deprivation suppresses stress-induced rise in catabolic hormones with a concomitant tendency to potentiate the increment of blood glucose. Physiology and Behaviour. Volume 48, Issue 4, 531-537.

94. Yanchev, I. ,Moneva, P., Gudev, D., Popova-ralcheva, S., Reeva, Tz., Penchev,P. and Ilieva, I. 2008. Effect of weaning on some plasma metabolites in Black-and-White calves fed diets with or without supplemental chromium picolinate. Bulgarian J. of Agric. Sci., 14(3):329-334.

95. Yousef HM and Zaki AA. 2001. Effect of barley radical feeding on body weight gain and some physiological parameters of growing Friesian crossbred calves. Egypt J. Nutri and Feeds 4: 565- 472.

96. Zanouny, A. E. I. 2011. Studies on some productive and physiological traits in Ossimi sheep. Ph.D. Thesis, Faculty of Agriculture, El-Minia University, Egypt. 